\title{
Constitutional Obstacles? Reconsidering Copyright Protection for Pre-1972 Sound Recordings
}

\author{
Eva E. Subotnik* \\ June M. Besek** \\ Introduction \\ 328 \\ I. Background \\ .329

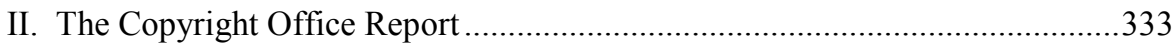 \\ III. Potential Legal Effects of Federalization ………….......................................335

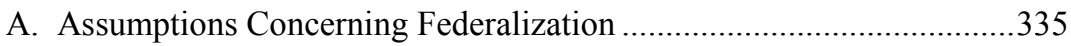

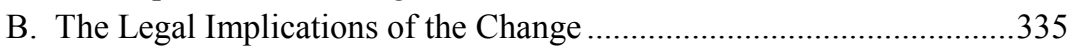

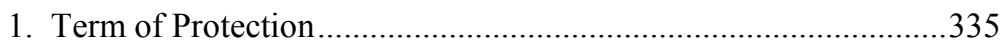

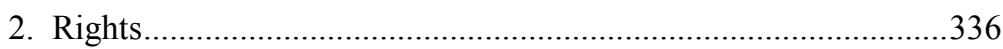

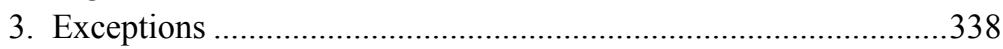

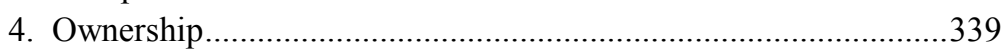

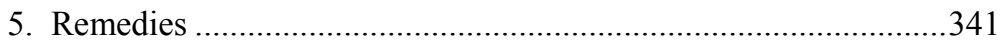

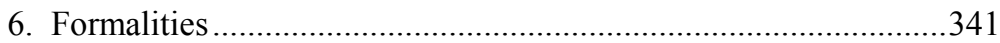 \\ C. Potential Plaintiffs Who Might Claim a Constitutional Deprivation ...342

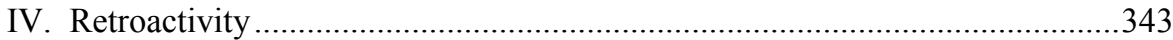

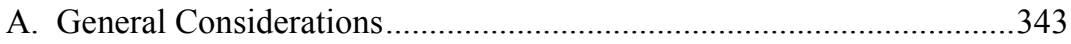

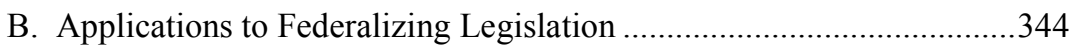

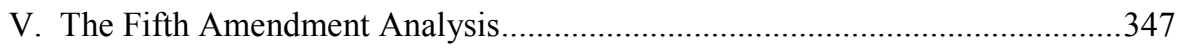

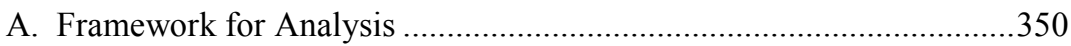 \\ B. Foreshortened Term of Protection ..........................................................353

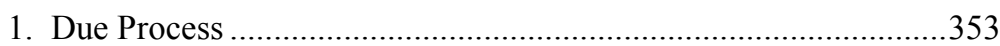

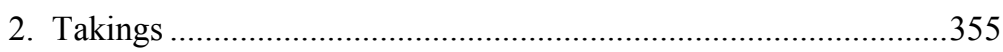

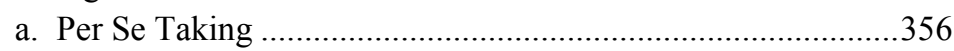 \\ b. Penn Central Taking ..................................................................360 \\ * Assistant Professor of Law, St. John's University School of Law. \\ ** Executive Director, Kernochan Center for Law, Media and the Arts and Lecturer-in-Law, \\ Columbia Law School. \\ We would like to thank the following people for their helpful contributions: Shyamkrishna \\ Balganesh, Christopher Beauchamp, Steven Bernstein, Robert Brauneis, Michael Burstein, Robert \\ Clarida, Matthew Aaron Collins, Elizabeth Townsend Gard, Camilla Hrdy, Brian Lee, Irina Manta, \\ Mary Rasenberger, Mark Weiner, the participants in the Faculty Workshop at St. John's University \\ School of Law, the participants in the Second Annual Intellectual Property Scholars' Roundtable at the \\ University of New Hampshire School of Law (2012), the participants in the Intellectual Property \\ Scholars Conference (2011) and especially Thomas Merrill and Christopher Serkin.
}




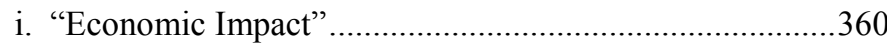

ii. "Distinct Investment-backed Expectations" ....................363

iii. "Character of the Governmental Action"........................366

C. Filing Obligations and Obligation to Make the Work Reasonably Available

D. Registration

E. Substitution of Federal Rights and Remedies ....................................372

F. Restrictions on Users.

Conclusion .378

\section{INTRODUCTION}

The typical complaint about intellectual property laws is that they are sluggish in responding to technological change. An unfolding question in the contemporary era, however, is the degree to which the threat of constitutional challenge will lead Congress to further adhere to the status quo. In the wake of the patent law overhaul several years ago, ${ }^{1}$ for example, the wisdom and scope of those amendments were widely debated, but concern about their constitutional soundness was also expressed in some quarters. ${ }^{2}$ Likewise, the latter concern is in play with respect to a proposed amendment of the law that applies to sound recordings.

Amidst the waves of technological innovation affecting access to music, the eyes and ears of the music industry, library associations, policy makers and others are focused on a legislative decision made some four decades ago. Specifically, these parties are staking out their positions on the possibility of extending federal copyright protection to pre-1972 sound recordings. ${ }^{3}$ Those sound recordings are currently protected through 2067 by a patchwork of state laws, and after that date all pre-1972 sound recordings will enter the public domain. ${ }^{4}$

The U.S. Copyright Office has issued a report recommending that pre-1972 sound recordings be brought under federal copyright protection in the near future. ${ }^{5}$ There are sound reasons for doing so. The Office's proposal would result in a shorter term of protection for some recordings and effect other changes in the rights and responsibilities of right holders and users.

1. Leahy-Smith America Invents Act (AIA), Pub. L. No. 112-29, 125 Stat. 284 (2011) (codified in scattered sections of 35 U.S.C.).

2. See, e.g., Brooks v. Dunlop Mfg. Inc., 702 F.3d 624, 626 (Fed. Cir. 2012) (rejecting constitutional challenge); Andrew L. Sharp, Note, Misguided Patent Reform: The Questionable Constitutionality of First-to-File, 84 U. COLO. L. REV. 1227 (2013).

3. See, e.g., John Conyers, Music Legends Deserve R-E-S-P-E-C-T, USA TODAY (Dec. 1, 2013, 5:41 PM) http://www.usatoday.com/story/opinion/2013/12/01/john-conyers-music-copyright-column/ 3797485 .

4. $\quad 17$ U.S.C. $\S 301(c)(2012)$.

5. Register of Copyrights, Federal Protection for Pre-1972 Sound ReCORdings (2011), available at http://www.copyright.gov/docs/sound/pre-72-report.pdf [hereinafter COPYRIGHT OFFICE REPORT]. One of the coauthors of this Article, June M. Besek, served as a consultant to the U.S. Copyright Office in connection with the Copyright Office Report. 
This Article examines the constitutional implications of legislation to bring pre1972 sound recordings under federal copyright protection (referred to hereafter as "federalizing legislation"). In particular, we consider whether such an amendment could violate due process or constitute a taking pursuant to the Fifth Amendment of the Constitution. ${ }^{6}$ Using the Copyright Office's approach as a springboard, we consider the issues that would likely arise under any federalizing legislation. These issues, however, have implications far beyond the context of federalizing legislation for pre-1972 sound recordings. Given the proliferation of assets subject to intellectual property laws and the increasing role those assets play in the U.S. economy, the questions addressed in this Article may bear on Congress' overall ability to amend those laws. ${ }^{7}$

This Article first lays out the relevant background to the special treatment of pre-1972 sound recordings. It then describes the legislative changes proposed by the Copyright Office. The Article identifies the most likely points of contention among the various stakeholders concerning federalizing legislation. It then assesses the viability of potential takings and due process claims. We conclude that if Congress were to adopt the type of proposal offered by the Copyright Office, along with the modifications suggested herein, the principal takings and due process concerns would be significantly alleviated. Such legislation could serve as a helpful framework for future amendments to the intellectual property laws.

\section{BACKGROUND}

Although they had existed in various formats for over one hundred years, ${ }^{8}$ sound recordings only received federal copyright protection in the United States effective February 15, 1972 through the Sound Recording Amendment. ${ }^{9}$ That protection extended prospectively to sound recordings fixed on or after that date. Sound recordings fixed prior to February 15, 1972 ("pre-1972 sound recordings") continued to be protected under state law, where they remain today. At the time of the Sound Recording Amendment, most unpublished works in all media were also

6. The Fifth Amendment provides: "No person shall be ... deprived of life, liberty, or property, without due process of law; nor shall private property be taken for public use, without just compensation." U.S. CONST. amend. V.

7. For example, the U.S. Register of Copyrights has called for a comprehensive review of the Copyright Act, suggesting, inter alia, that Congress may want to alleviate the gridlock resulting from the lengthy term of copyright "by reverting works to the public domain after a period of life plus fifty years unless heirs or successors register their interests with the Copyright Office." The Register's Call for Updates to the U.S. Copyright Law: Hearing Before the Subcomm. on Courts, Intell. Prop. \& the Internet of the H. Comm. on the Judiciary, 113th Cong. 7 (2013) (statement of Maria A. Pallante, U.S. Register of Copyrights).

8. One of the earliest recordings is the French folksong "Au Clair de la Lune," recorded on April 9, 1860 by Parisian Édouard-Léon Scott de Martinville. See Édouard-Léon Scott de Martinville's Phonautograms, FIRST SOUNDS (May 29, 2009), http://www.firstsounds.org/sounds/scott.php.

9. The Sound Recording Amendment, Pub. L. No. 92-140, 85 Stat. 391 (1971) (codified in scattered sections of 17 U.S.C.). The law was passed on October 15, 1971, and went into effect on February 15, 1972. Id. § 3 . 
protected exclusively by state law. ${ }^{10}$

In 1976, Congress created a unitary system of copyright. The 1976 Copyright Act explicitly extended federal copyright protection to unpublished works, ${ }^{11}$ which, up until that point, had enjoyed perpetual protection under state law. The Act also preempted rights equivalent to federal copyright that might be available under state common law or state statutory law. ${ }^{12}$ However, it left pre-1972 sound recordings, ${ }^{13}$ published or not, exclusively under state law protection until they enter the public domain on February 15, 2067. ${ }^{14}$

In recent years, scholarly groups seeking to promote the preservation and study of sound recordings have urged that pre-1972 sound recordings be brought under federal copyright law. ${ }^{15}$ In 2009, Congress directed the U.S. Copyright Office to evaluate the implications of such a change on the preservation of and access to sound recordings as well as the potential economic impact on right holders. ${ }^{16}$ In its December 2011 report, the Office concluded that the best course is for Congress to federalize protection for these older recordings. ${ }^{17}$

There are several reasons for Congress to extend federal protection to pre-1972 sound recordings. First, the elimination of disparate sources of protection in favor of a single federal scheme-with a clearer, better defined regime for the enforcement of rights - would better implement "the basic constitutional aims of

10. Under the 1909 federal Copyright Act, works were eligible for federal protection only upon publication with a proper copyright notice. Some categories of works could be federally registered as unpublished under the 1909 federal Copyright Act. Courts generally held that such a federal registration divested the work of any state common law rights. See 2 Melville B. Nimmer \& DAVID Nimmer, NIMMER ON COPYRIGHT § 7.16[A][2][c][i]-[ii] (rev. ed. 2013) [hereinafter NIMMER ON COPYRIGHT].

11. 17 U.S.C. $\S 303($ a) (2012).

12. 17 U.S.C. $\$ 301(a)$.

13. Sound recordings are "works that result from the fixation of a series of musical, spoken, or other sounds, but not including the sounds accompanying a motion picture or other audiovisual work, regardless of the nature of the material objects, such as disks, tapes, or other phonorecords, in which they are embodied." 17 U.S.C. § 101.

14. 17 U.S.C. $\S 301(c)$. The complete subsection states:

With respect to sound recordings fixed before February 15, 1972, any rights or remedies under the common law or statutes of any State shall not be annulled or limited by this title until February 15, 2067. The preemptive provisions of subsection (a) shall apply to any such rights and remedies pertaining to any cause of action arising from undertakings commenced on and after February 15, 2067. Notwithstanding the provisions of section 303, no sound recording fixed before February 15, 1972, shall be subject to copyright under this title before, on, or after February 15, 2067.

Id. As passed in 1976, the legislation provided that state laws would not be preempted until February 15, 2047, but that date was extended to February 15, 2067 by the Copyright Term Extension Act, Pub. L. No. 105-298, 112 Stat. 2827 (1998).

15. See, e.g., ASSOC. FOR ReCORDED SOUND COLleCtions, LEgAL IMPEDIMENTS TO PRESERVATION OF AND ACCess to the Audio HeritAge of the United StATES (2007), available at http://www.arsc-audio.org/pdf/ARSC-MLAcopyright.pdf.

16. StafF of H. COMM. ON Appropriations, 111Th Cong., H.R. 1105, Pub. L. No. 111-8 [Legislative Text and Explanatory Statement] 1769 (Comm. Print 2009). See also Notice of Inquiry, Federal Copyright Protection of Sound Recordings Fixed Before February 15, 1972, 75 Fed. Reg. 67,777 (Nov. 3, 2010).

17. See COPYRIGHT OfFice RePORT, supra note 5, at 120. 
uniformity and the promotion of writing and scholarship." ${ }^{18}$ Currently, there is a significant disparity in the legal treatment of pre-1972 sound recordings, both with respect to the state laws and in comparison to other works of authorship protected under federal law. ${ }^{19}$ One consequence of this disparity is that there are almost no pre-1972 U.S. sound recordings in the public domain across the United States. ${ }^{20}$

Pre-1972 sound recordings are protected by an array of state laws, including criminal anti-piracy laws and civil laws - occasionally through civil statutes, but usually by common law under a range of different legal theories, including unfair competition, misappropriation, common law copyright and others. ${ }^{21}$ Some states have well-defined causes of action; others have no law directly on point. ${ }^{22}$ In some states, right holders may bring claims only against direct commercial competitors. ${ }^{23}$ Moreover, states generally do not provide explicit protection for all of the same rights that are protected under federal law; for example, digital streaming is embraced under the federal right of public performance, but may have no explicit state law protection. ${ }^{24}$

Second, federal protection would permit scholars, researchers and others seeking to use pre-1972 sound recordings to benefit from vital exceptions and defenses to alleged infringement, such as fair use and the privileges for libraries and archives in $\S 108 .{ }^{25}$ As mentioned, states are entitled to protect pre-1972 sound recordings until 2067. Some states provide for a specific end date before 2067 for such protection, but most do not. ${ }^{26}$ Even recordings dating from the beginning of the

18. H.R. REP. NO. 94-1476, at 129 (1976) (setting out this goal as a basis for supporting the 1976 Copyright Act).

19. See Copyright OfFice Report, supra note 5, at 13-17, 20-49.

20. See id. at 5. Sound recordings published without copyright notice from 1972-1989 are now in the public domain, absent mitigating circumstances. Id. at 5 n.13. There are some pre-1972 sound recordings that are no longer protected in a particular state or states, but very few are in the public domain nationwide. See, e.g., Capitol Records, Inc. v. Naxos of Am., Inc., 830 N.E.2d 250 (N.Y. 2005) (affirming New York's ability to grant common law copyright protection to pre-1976 sound recordings that were in the public domain in their country of origin).

21. June M. Besek, Copyright and Related Issues Relevant to Digital Preservation AND DisSEMINATION OF UNPUBLISHED PRE-1972 SOUND RECORDINGS By LibRARIES AND ARCHIVES 37-39 (2009). States may protect unpublished sound recordings under common law copyright, even if they impose a different regime of protection on published sound recordings. PROGRAM ON INFO.

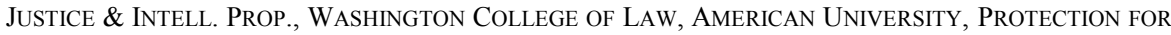
Pre-1972 SOUnd Recordings Under State LaW and ItS Impact on Use by NonProfit INSTITUTIONS: A 10-STATE ANALYSIS 15-19 (2009) [hereinafter Jaszi Report].

22. See COPYRIGHT OfFICE RePORT, supra note 5, at 48. It is impossible, however, to rule out the prospect of protection pursuant to common law tort claims, as the common law evolves over time. See id.

23. See id. at $35-36,47$.

24. 17 U.S.C. $\S \S 106(6), 114$ (2012). Other differences between state protection and federal protection will be discussed in greater detail below.

25. See 17 U.S.C. $\S \S 107,108$. Section 108 permits libraries and archives to make copies of protected works for preservation and replacement, and for individual users, under defined circumstances. Id. $\S 108$.

26. California, for example, protects sound recordings only until February 15, 2047. CAL. CIV. CODE $\S 980(a)(2)$ (West 2012). Colorado law provides that, for purposes of criminal enforcement, a common law copyright may not last longer than 56 years from when it accrues. COLO. REV. STAT. § 18- 
twentieth century can potentially enjoy protection in many states.

Because of the amorphous nature of civil law protection in many states, the availability and scope of exceptions akin to fair use or those for libraries and archives is uncertain. ${ }^{27}$ Compounding the problem is the reluctance of many librarians and archivists to make certain uses of recordings when the law is ambiguous. $^{28}$ There is also the concern that even if a use is permissible under a home state's laws, it may be actionable elsewhere. ${ }^{29}$ Indeed, the issues raised by librarians and archivists, and the effect of federalization of pre-1972 sound recordings on preservation, were a principal focus of the Copyright Office Study. ${ }^{30}$ Libraries and archives have also indicated that the absence of clear legal authority concerning preservation of, and access to, pre-1972 sound recordings adversely affects their ability to raise funds for preservation initiatives. ${ }^{31}$

Third, granting federal copyright protection would reduce the disparate treatment of foreign and domestic pre-1972 sound recordings. Certain foreign pre1972 sound recordings are protected by federal copyright law. In implementing U.S. obligations under the TRIPS Agreement, ${ }^{32}$ Congress provided federal copyright protection for eligible sound recordings of foreign origin which were fixed before February 15, 1972. 33 For most works, this "copyright restoration"

4-601(1.5) (2012). 2067 is effectively the end date in the many states that protect sound recordings pursuant to common law causes of action, for which there is often no specific end date under state law. See generally COPYRIGHT OFFICE REPORT, supra note 5, at 47.

27. See COPYRIGHT OFFICE REPORT, supra note 5, at 46. In some states that provide protection pursuant to a tort cause of action, certain activities permitted by exceptions under federal copyright law may be nonactionable because they do not cause a competitive injury (e.g., they involve uses of the recordings by persons other than competitors). But there nevertheless remains ambiguity about the permissibility of certain uses of sound recordings. This concern weighs more heavily in states like New York that base protection on common law copyright, which does not require a competitive injury as a component of a claim. See Capitol Records, Inc. v. Naxos of Am., Inc., 830 N.E.2d 250, 266 (N.Y. 2005).

28. See, e.g., Patrick Loughney, Library of Congress, Comments of Library of Congress in Response to Notice of Inquiry, in U.S. COPYRIGHT OFFICE, COMMENTS REGARDING FEDERAL Copyright Protection of Sound Recordings FiXed Before Feb. 15, 1972, at 6 (Nov. 3, 2011), available at http:/www.copyright.gov/docs/sound/comments/initial [hereinafter Loughney, Comments of Library of Congress in Response to Notice of Inquiry]; Tim Brooks, Ass'n of Recorded Sound Collections, Comments at Pre-1972 Sound Recordings Public Meeting 194 (June 2, 2011), available at http://www.copyright.gov/docs/sound/meeting/transcript-06-02-2011.pdf [hereinafter Brooks, Comments at Pre-1972 Sound Recordings Public Meeting].

29. See, e.g., Brooks, Comments at Pre-1972 Sound Recordings Public Meeting, supra note 28, at $36-37$.

30. See 155 Cong. Rec. H2397 (2009) (directing the Copyright Office to study "the effect of federal coverage on the preservation of [pre-1972] sound recordings, the effect on public access to those recordings, and the economic impact of federal coverage on rights holders").

31. Loughney, Comments of Library of Congress in Response to Notice of Inquiry, supra note 28, at 3-5; Sam Brylawski, Soc. for Am. Music, Comments at Pre-1972 Sound Recordings Public Meeting 51 (June 2, 2011), available at http://www.copyright.gov/docs/sound/meeting/transcript-06-022011.pdf.

32. Trade-Related Aspects of Intellectual Property Rights ("TRIPS"), Apr. 15, 1994, 33 I.L.M. 1199 (1994). U.S. obligations under TRIPS were implemented in the Uruguay Round Agreements Act, Pub. L. No. 103-465, 108 Stat. 4809 (1994) (codified as amended at 17 U.S.C. $\S \S 104 A, 109$ ).

33. See 17 U.S.C. $\S 104 \mathrm{~A}(\mathrm{a})(1)$, (h)(6)(C) (2012). Eligible sound recordings were those which 
occurred automatically on January $1,1996,{ }^{34}$ and restored works are protected in the United States for the remainder of the term they would have enjoyed had they not entered the public domain. ${ }^{35}$ In many foreign countries, the term of protection for sound recordings on January 1, 1996 was fifty years from first publication or fixation. ${ }^{36}$ Consequently, most foreign sound recordings first fixed in 1946 or later have federal copyright protection. ${ }^{37}$

Thus, the disparity in the protections for sound recordings in the United States weighs in favor of adopting federal copyright protection for pre-1972 sound recordings.

\section{THE COPYRIGHT OFFICE REPORT}

In its December 2011 Report, Federal Protection for Pre-1972 Sound Recordings, the Copyright Office concluded that federalization "would best serve the interest of libraries, archives and others in preserving old sound recordings and increasing the availability to the public of old sound recordings." ${ }^{38}$ Recognizing that librarians and archivists find the scope of existing federal copyright exceptions problematic, the Office nevertheless concluded that federal law would provide greater certainty and more opportunity to preserve and increase public access to old sound recordings than the current state law regime does. ${ }^{39}$ It also concluded that the objections raised by the record companies - principally, that the change would wreak havoc on existing ownership rights - could be satisfactorily addressed by drafting the legislation so as to ensure that it did not effect a change in ownership

were not in the public domain in their source country on the date of restoration due to expiration of the term of protection, had at least one author or right holder who was a national or domiciliary of an eligible country when the work was created and (if published) were published in an eligible country and not published in the United States within thirty days after foreign publication. $I d$. § 104A(a)(1), (h)(6).

34. For works whose source countries were members of the Berne Convention or the WTO at the time, the restoration date was January 1, 1996; for countries that joined later, it was the date of adherence. 17 U.S.C. $\S 104 \mathrm{~A}(\mathrm{~h})(2)$. This legislation is referred to as "copyright restoration" because it provided that copyright would be restored to many works that previously had but then lost protection. Pre-1972 sound recordings, however, were never eligible for federal copyright.

35. 17 U.S.C. $§ 104 A(a)(1)$. See also Golan v. Holder, 132 S. Ct. 873 (2012) (holding that the URAA's copyright restoration provisions were within Congress's authority under the Copyright Clause of the Constitution, and the removal of works from the public domain did not violate the First Amendment rights of reliance parties who were using the works prior to restoration).

36. This is the minimum term of protection provided by the WIPO Performances and Phonograms Treaty art. 17, Dec. 20, 1996, S. TREATY Doc. No. 105-17, 36 I.L.M. 76. The European Union recently extended the term of protection for sound recordings (phonograms) to 70 years. Directive 2011/77/EU of the European Parliament and of the Council, 2011 O.J. (L 265) (Sept. 27, 2011). Implementation of the extension was required by Nov. 1, 2013 and does not apply to sound recordings already in the public domain. See id.

37. Conversely, almost all pre-1946 foreign sound recordings are in the public domain as far as federal copyright law is concerned. However, these pre-1946 foreign sound recordings may still be protected under state law. See Capitol Records, Inc. v. Naxos of Am., Inc., 830 N.E.2d 250, 263-66 (N.Y. 2005).

38. COPYRIGHT OFFICE REPORT, supra note 5, at viii.

39. Id. 
of rights in pre-1972 sound recordings. ${ }^{40}$

Specifically, the Office recommended that pre-1972 sound recordings be brought under federal copyright law with the same rights, exceptions and limitations as sound recordings created in 1972 and thereafter. ${ }^{41}$ Furthermore, the initial owner of the federal copyright would be the person who owns the rights in the recording under state law just prior to when the federal law becomes effective. ${ }^{42}$

The proposed scheme would effectively give all newly-federalized sound recordings, no matter how old, some minimum period of protection. ${ }^{43}$ Sound recordings published before 1923 would get a "transition period" of at least three years of federal protection, with the possibility of twenty-five years in total if, during the transition period, the right holder met certain "extended term requirements," which entail: (1) making the sound recording available to the public at a reasonable price; (2) filing a notice in the Copyright Office to signify its intent to achieve maximum protection and (3) continuing to make the work available at a reasonable price throughout the extended term. ${ }^{44}$

Sound recordings published in 1923 or later would be protected until the expiration of ninety-five years from first publication (as defined by the federal copyright law), ${ }^{45}$ though they would get a transition period of six to ten years of protection and the further possibility of federal protection until February 15, 2067 through compliance with the extended term requirements. Sound recordings unpublished as of the effective date of the federalizing legislation would get a term of 120 years from fixation, or to the end of a six-to-ten-year transition period (whichever expires later), but in no event beyond $2067 . .^{46}$ If the 120 -year term would expire before 2067, the unpublished sound recordings-like sound

40. Id.

41. Id. at $\mathrm{ix}-\mathrm{x}$

42. The Report also recognized that certain adjustments should be considered with respect to the federal requirements of timely registration as a prerequisite to an award of attorney's fees and statutory damages in an infringement suit, and to other provisions such as 17 U.S.C. $\S 205$ (2012), which deals with priority of conflicting transfers.

43. The proposed terms are analogous to the terms of protection provided for works created prior to the effective date of the 1976 Copyright Act. See 17 U.S.C. $\S \S 303,304(a)-(b)$. However, the Office purposely suggested a term that did not rely on a measuring life, in contrast to unpublished works brought under federal law in the 1976 Copyright Act, which received a term of life plus fifty years (later extended to life plus seventy years), as well as a minimum term of at least twenty-five years under 17 U.S.C. $\S 303$.

44. COPYRIGHT OFFICE REPORT, supra note 5, at 177. The Report addressed the possibility of a Fifth Amendment takings claim and concluded that various aspects of its proposed legislation, including the transition period and the opportunity to achieve a longer period of protection, "significantly diminish[] . . the likelihood of success of any takings claim . . . " Id. at 166-67.

45. 17 U.S.C. $§ 101$ (2011) defines "publication" as:

[t]he distribution of copies or phonorecords of a work to the public by sale or other transfer of ownership, or by rental, lease, or lending. The offering to distribute copies or phonorecords to a group of persons for purposes of further distribution, public performance, or public display, constitutes publication. A public performance or display of a work does not of itself constitute publication.

Id.

46. COPYRIGHT OFFICE REPORT, supra note 5, at ix. 
recordings published in 1923 or later-would have the possibility of protection until 2067 through compliance with the extended term requirements.

\section{POTENTIAL LEGAL EFFECTS OF FEDERALIZATION}

\section{A. Assumptions ConCerning Federalization}

In analyzing whether federalizing legislation would encroach on rights guaranteed by the Fifth Amendment, we operate on the assumption that the legislation would follow the broad outlines of the U.S. Copyright Office's proposal, discussed above. That this formulation, informed as it was by comments from many of the relevant stakeholders, is a useful starting point for our discussion. Even if federalizing legislation as enacted differs from the Copyright Office's proposal, the due process and takings concerns discussed below will remain relevant. Accordingly, as of the effective date of the legislation (assumed, for the purposes of this article, to be January 1, 2015), all pre-1972 sound recordings would be protected under federal copyright law, and all state rights with respect to copyright and copyright-like protection of pre-1972 sound recordings would be preempted.

Pre-1972 sound recordings would have the term of protection described in the Copyright Office Report, discussed above. A transition period of three years for sound recordings published prior to 1923 and a transition period of six years for other pre-1972 sound recordings will be assumed.

\section{B. The Legal IMPLiCATIONS OF THE Change}

If protection for pre-1972 sound recordings were brought under federal law, how would the nature and scope of protection differ from what it is now? ${ }^{47}$

\section{Term of Protection}

If federalization of pre-1972 sound recordings effected a significant reduction in the term of protection, it could diminish an expected income stream for right holders who might otherwise market recordings with commercial value. The impact of federalization on the expected income stream would vary substantially with the value of the individual recording and with the number of years by which the term is diminished.

The potential term change is best analyzed with specific examples. In each of the examples below, the term of protection the recording would receive under the hypothetical federalizing statute is compared to a term of protection in New York, where pre-1972 sound recordings, whether published or not, are protected by

47. A comparison between state and federal law protection could itself be the basis of a law review article. We have tried to highlight here the principal differences that might bear on the takings and due process issues. 
common law copyright until $2067 .^{48}$

1920 published recording: Under the federalizing legislation, protection for such a recording would expire on January 1, 2018 (three years from the effective date of the legislation) unless, during that three-year transition period, the right holder were to meet the extended term requirements, in which case the recording would be protected under federal law for a total of twenty-five years, until 2040. Thus the term will be reduced by at least twenty-seven years in comparison with New York (2067-2040), and as much as forty-nine years if the right holder fails to meet the extended term requirements (2067-2018). ${ }^{49}$

1923 published recording: Under the federalizing legislation, protection would last until 2018 (ninety-five years from publication), but the assumed six-year transition period would ensure protection until the beginning of 2021, for a loss of forty-six years of protection in comparison with New York (2067-2021). A right holder could, however, achieve federal protection until 2067 by meeting the extended term requirements.

1960 published recording: Under the federalizing legislation, protection would expire in 2055 (ninety-five years from publication), for a loss of twelve years of protection compared with New York (2067-2055). A right holder could, however, get federal protection until 2067 by meeting the extended term requirement.

Unpublished recording created in 1940: ${ }^{.0}$ Under the federalizing legislation, unpublished recordings would be protected until 120 years after fixation, but no later than 2067. So the sound recording in question would be protected until 2060 (for a loss of seven years compared with New York), or until 2067 if the right holder meets the extended term requirements.

Unpublished recording created in 1970: Under the federalizing legislation, the term would last until 120 years after fixation, but no later than 2067. Since 1970 plus 120 years would be 2090, the unpublished recording would be protected under federal law until 2067 but no longer, and federalization would not alter its term of protection as compared with New York.

\section{Rights}

Federal copyright law provides right holders with a set of rights: reproduction,

48. See Capitol Records, Inc. v. Naxos of Am., Inc., 830 N.E.2d 250 (N.Y. 2005). Many states base protection on common law unfair competition principles, which have no temporal endpoint (other than the externally imposed federal preemption deadline of 2067); but protection would effectively cease if the sound recording at issue had no commercial value, so for any given recording, the term may effectively be shorter than 2047. The differences among states might become relevant if a right holder were to bring an "as applied" challenge alleging a taking had occurred.

49. These dates are approximate because federal preemption occurs on Feb. 15, 2067, 17 U.S.C. $\S 301(\mathrm{c})$, but federal terms generally last until the end of the year in which they would otherwise expire, 17 U.S.C. $\S 305$.

50. While one might argue that a sound recording that has not been commercialized is less likely to create a takings problem, it does not necessarily follow that such recordings have no commercial value (such that takings claims could not even be raised). 
adaptation, distribution, public performance and public display. ${ }^{51}$ The public performance right in sound recordings is limited to the right "to perform the work publicly by means of a digital audio transmission." ${ }^{52}$ Performance by other means, such as analog transmission, is not restricted by federal copyright. ${ }^{53}$

Although not technically a "right" of the owner, some protection for pre-1972 sound recordings is provided by criminal anti-piracy laws in nearly every state, although the laws vary and it is not clear how many cases are brought pursuant to these laws. ${ }^{54}$ On the civil side, states generally provide protection for pre-1972 sound recordings through common law, although some states, like California, have civil statutes that address unauthorized use of pre-1972 sound recordings. States may treat unauthorized reproduction and distribution of pre-1972 sound recordings as unfair competition or misappropriation, a violation of "common law copyright," or as another type of civil wrong. ${ }^{55}$ Where the cause of action is grounded in unfair competition or misappropriation, evidence of a competing use and/or commercial benefit to the user is usually required to establish a claim. A claim grounded in common law copyright does not require such a showing. ${ }^{56}$

It is apparent that duplication and distribution rights are recognized under state law. ${ }^{57}$ The existence of a derivative work right under state law is less well established; there is some support for its existence, but there are too few cases to establish whether it can be considered similar in scope to the derivative work right under federal law. ${ }^{58}$

51. 17 U.S.C. $\S 106$. The federal display right is not of major significance for sound recordings themselves, though it may be for cover artwork.

52. 17 U.S.C. § 106(6). See Digital Performance Right in Sound Recordings Act of 1995, Pub. L. No. 104-39, 109 Stat. 336 (1995), amended by the Digital Millennium Copyright Act of 1998, Pub. L. No. 105-304, 112 Stat. 2860 (1998) (codified at 17 U.S.C. $\$ 114$ (2000)). Certain types of digital audio transmissions, such as webcasting, are subject to a statutory license. The sound recording copyright owner may not prevent these transmissions, but the transmitting party must pay royalties. 17 U.S.C. $\S 114(\mathrm{~d})(2)$. The rate is set by the Copyright Royalty Board, and the royalties are distributed to recording companies and performers by an organization called SoundExchange. Performances such as interactive digital audio services (on-demand streaming) that are perceived to involve a high risk of copying, or of substituting for the sale of copies, require a negotiated license. 17 U.S.C. $\S 114(\mathrm{~d})(2)$, (3), (4)(A).

53. Legislation is pending in Congress to, inter alia, include audio transmissions within the public performance right for sound recordings. Free Market Royalty Act, H.R. 3219, 113th Cong. (2013).

54. See COPYRIGHT OfFICE REPORT, supra note 5, at 20-28.

55. Id. at 28-43; see also Jaszi Report, supra note 21, at 13-19. Some states have no reported cases on pre-1972 sound recordings, so it is unclear whether and how they would provide civil law protection against unauthorized uses. Most states would likely protect unpublished sound recordings under a common law copyright regime. See id. at 4-5 (explaining that common law copyright protects against unauthorized use of recordings prior to their first publication).

56. See, e.g., Capitol Records, Inc. v. Naxos of Am., Inc., 830 N.E.2d 250, 266 (N.Y. 2005).

57. See, e.g., Columbia Broad. Sys., Inc. v. Melody Recordings, Inc., 341 A.2d 348 (N.J. Super. Ct. App. Div. 1975); Capitol Records, Inc. v. Erickson, 82 Cal. Rptr. 798 (Cal. Ct. App. 1969).

58. In Capitol Records v. Naxos, for example, the New York Court of Appeals rejected Naxos's claim that its remastering of the Capitol recordings to enhance sound quality resulted in "new products" that did not infringe the originals, since the remastered recordings still utilized elements of the original recordings. Capitol Records, Inc., 830 N.E.2d at 267. The federal derivative work right for sound recordings is narrower than that for other copyrighted works; it does not encompass imitations of a 
In general, states do not appear to recognize a right of public performance in pre-1972 sound recordings, ${ }^{59}$ and a few states restrict such a right by statute. ${ }^{60}$ Such recordings are regularly played, broadcast and streamed without a performing rights license; ${ }^{61}$ they do not have the benefit of an explicit right of public performance by means of digital audio transmissions provided to federally protected sound recordings by $\S 106(6)$ of the Copyright Act. ${ }^{62}$

Thus, bringing pre-1972 sound recordings under the protection of federal law would provide right holders with a clearer and more consistent set of rights, including a better defined derivative work right, as well as a right of public performance for digital transmissions. ${ }^{63}$

\section{Exceptions}

Federal copyrights are subject to various exceptions and limitations, as set out in $\S \S 107$ to 122 of the Act. The exceptions include, inter alia, fair use, exceptions for libraries and archives and educational exceptions for face-to-face classroom use and distance education. ${ }^{64}$

It is often unclear what exceptions and limitations are available under the various state laws. ${ }^{65}$ Most of the state cases involve commercial duplication and distribution of entire recordings, and there is little law addressing commercial, transformative uses of less than an entire recording, such as might be found in typical sampling practices, or noncommercial uses generally. In many states, noncommercial uses for scholarship, teaching and preservation would simply not

performance in a sound recording if the sounds in the recording are independently fixed. 17 U.S.C. $\S$ 114(b) (2012). Performers have succeeded in bringing "right of publicity" actions against sound-alikes under state law. See, e.g., Midler v. Ford Motor Co., 849 F.2d 460 (9th Cir. 1988). Presumably, such holdings would be unaffected by federalizing protection for pre-1972 sound recordings.

59. See, e.g., RCA Mfg. Co. v. Whiteman, 114 F.2d 86, 89-90 (2d Cir. 1940).

60. See, e.g., N.C. GEN. STAT. § 66-28 (2012); S.C. CODE ANN. § 39-3-510 (2011).

61. See David Oxenford, Nat'l Ass'n of Broadcasters, Comments at Pre-1972 Sound Recordings Public Meeting 326-27 (June 2, 2011), available at http://www.copyright.gov/docs/sound/meeting/ transcript-06-02-2011.pdf; see generally R. Bruce Rich, Todd D. Larson \& Cynthia Greer, Sirius XM Radio, Comments of Sirius XM Radio in Response to Notice of Inquiry, in U.S. COPYRIGHT OFFICE, Comments Regarding Federal Copyright Protection of Sound Recordings Fixed Before FEB. 15, 1972 (2011), available at http://www.copyright.gov/docs/sound/comments/reply.

62. See 17 U.S.C. $\$ \S 106(6), 114$. It is possible that a court might find streaming, particularly ondemand streaming, to be a violation of state rights in a pre-1972 sound recording because it could, in effect, substitute for a purchase of the recording. However, no court has yet been confronted with this issue, which will likely be resolved in the context of pending suits. See, e.g., Complaint at 6, SoundExchange, Inc. v. Sirius XM Radio Inc., No. 1:13-CV-01290, 2013 WL 521902 (D.D.C. Aug. 26, 2013) (alleging that Sirius withheld from SoundExchange royalties owed for the performance of pre1972 sound recordings, in violation of $\S \S 112$ and 114 of the Copyright Act); see also Hannah Karp, Sirius is Sued Over Music Royalties for Pre-1972 Recordings, WALl St. J. (Aug. 26, 2013), http://online.wsj.com/news/articles/SB10001424127887324591204579037260890310376.

63. 17 U.S.C. $\S \S 106,114$.

64. 17 U.S.C. $\$ \S 107,108,110(1)-(2)$.

65. The California civil statute has exceptions, as do many state criminal laws (discussed below), but they do not cover the range of uses for which exceptions are available under federal law. See COPYRIGHT OFFICE REPORT, supra note 5, at 26-27. 
meet the criteria for a cause of action under state law, since there is no commercial benefit to the user. ${ }^{66}$

State common law copyright provides a broad form of protection to right holders that is more analogous to federal copyright, since no competitive injury need be shown. While a recent New York case applied fair use under common law to the use of a pre-1972 sound recording, ${ }^{67}$ that is but a single state law case, and provides no basis from which to conclude that other state courts would apply a robust fair use doctrine. Moreover, there are no state common law doctrines analogous to other federal law exceptions, such as $\S 110$ (2) for distance education or $\S 108$ for library and archive uses. If protection for pre-1972 sound recordings were federalized, fair use and library exceptions would be consistently available. ${ }^{68}$

\section{Ownership}

The laws regarding ownership and transfers of rights in sound recordings may differ between state and federal law. For example, federal copyright law contains provisions to determine who the initial author of a work is, and whether a valid transfer of copyright rights has occurred. Under federal law, the individual creator of a work is the initial author unless the work is a "work made for hire." 69 If the work qualifies as a work made for hire, then the employer or commissioning party, and not the individual creator, is deemed the author (and thus the initial owner of all rights, unless the parties agree otherwise) ${ }^{70}$ The extent to which any particular state would recognize the work made for hire doctrine with respect to pre-1972 sound recordings, and under what circumstances, is unclear; in many states, there

66. See id. at 27; Jaszi Report, supra note 21, at 10-11.

67. EMI Records Ltd. v. Premise Media Corp., No. 601209/08, 2008 N.Y. Misc. Lexis 7485 (N.Y. Sup. Ct. Aug. 13, 2008).

68. Another change that might occur if pre-1972 sound recordings were brought under federal protection has to do with the safe harbor from copyright liability for service providers in $\S 512$ of the federal copyright law. Two courts have now read $\S 512$ to encompass common law copyright claims concerning pre-1972 sound recordings. Capitol Records, Inc. v. MP3Tunes, LLC, 821 F.Supp.2d 627, 640-42 (S.D.N.Y. 2011); UMG Recordings, Inc. v. Escape Media Grp., Inc., 948 N.Y.S.2d 881, 886-87 (N.Y. Sup. Ct. 2012). If these rulings are sustained, it appears that federalization of pre-1972 sound recordings would work no change, at least as to claims denominated as "copyright." See Capitol Records, LLC v. Vimeo, LLC, Nos. 09 Civ. 10101(RA), 09 Civ. 10105(RA), 2013 WL 5272932 (S.D.N.Y. Sept. 18, 2013) (denying safe harbor protection for pre-1972 sound recordings), certified for interlocutory appeal, Capitol Records, LLC v. Vimeo, LLC Nos. 09 Civ. 10101(RA), 09 Civ. 10105(RA), 2013 WL 6869648 (S.D.N.Y. Dec. 31, 2013); COPYRIGHT OFFICE REPORT, supra note 5, at 130-32 (expressing doubts about whether $\S 512$ encompasses common law copyright claims concerning pre-1972 sound recordings). Nevertheless, other types of claims with respect to pre-1972 sound recordings - unfair competition, misappropriation, conversion and the like - are presumably not covered by $\S 512$. See Michael Erlinger, Jr., An Analog Solution in a Digital World: Providing Federal Copyright Protection for Pre-1972 Sound Recordings, 16 UCLA ENT. L. REV. 45, 66 (2009). Accordingly, if pre-1972 sound recordings were brought under federal law, service providers would have a more comprehensive safe harbor with respect to those recordings.

69. 17 U.S.C. $\$ 201(\mathrm{a})-(\mathrm{b})$. For a detailed discussion of the work made for hire doctrine, see 2 NIMMER ON COPYRIGHT, supra note 10, at $\$ 5.03$ [A], [B][1][a][i].

70. 17 U.S.C. $\S 201(b)$. 
are no cases on point. ${ }^{71}$

Another principle of current federal copyright law is that ownership of the physical copy in which a protected work is embodied is distinct from ownership of the underlying intellectual property rights, and transfer of the physical object does not convey the underlying rights, in the absence of an agreement to that effect. ${ }^{72}$ State law applicable to pre-1972 recordings could differ. In some cases, courts prior to 1978 found that the sale or transfer of a material object also transferred the common law copyright with respect to the work embodied in that object, unless the creator specifically reserved those rights. ${ }^{73}$ This principle, sometimes referred to as the "Pushman doctrine," was repudiated by statute in New York and California, at least for works of fine art. ${ }^{74}$ Nevertheless, it remains possible that courts would apply this principle to pre-1972 sound recording masters, and this might vary from state to state. ${ }^{75}$

In any event, application of federal law rather than state law to pre-1972 sound recordings could effect a change in ownership, upsetting existing business expectations. To avoid potential confusion, federalizing legislation should provide that initial ownership of the federal copyright in these recordings be determined by state law, as would the validity of any transfers made prior to the effective date of the legislation. ${ }^{76}$ Even without an explicit statutory directive, it is likely that courts would endeavor to uphold expectations about ownership $;{ }^{77}$ nevertheless, an explicit

71. We thank Professor Elizabeth Townsend Gard, her student Dan Collier, and the Tulane Law Center for Intellectual Property, Media and Culture for providing us with helpful research on the methodologies for determining rights ownership in pre-1972 sound recordings under state law.

72. 17 U.S.C. $\$ 202$.

73. See, e.g., Pushman v. N.Y. Graphic Soc., Inc., 39 N.E.2d 249, 251 (N.Y. 1942) (“[A]n artist must, if he wishes to retain or protect the reproduction right, make some reservation of that right when he sells the painting.").

74. See 3 NimMER ON COPYRIGHT, supra note $10, \S 10.09[\mathrm{~B}][2]$.

75. See Polygram Records, Inc. v. Legacy Entm’t Grp., 205 S.W.3d 439 (Tenn. Ct. App. 2006) (owner of original acetate recordings of Hank Williams radio shows retrieved from the trash did not hold the intellectual property rights therein; possession of tangible copies alone did not convey intangible rights).

76. See COPYRIGHT OFFICE REPORT, supra note 5, at 147-48; accord Erlinger, supra note 68, at 75-76 ("Accordingly, the federal Copyright Act should not be used to determine ownership interests [including initial and transfer rights] in domestic, pre-1972 sound recordings. Rather, courts should look to determine ownership by applying the law of the state with the most significant relationship to the sound recording and the parties.").

77. By analogy, despite some initial concern that the 1976 Copyright Act might be applied to determine copyright ownership in works created before the Act came into effect, case law has not borne out this concern. See 1 NimMER ON COPYRIGHT, supra note $10, \S 1.11$. In litigation occurring after the effective date of the 1976 Act, courts have continued to look to the law in effect at the time of the relevant conduct - either the 1909 Copyright Act or state law - in determining copyright ownership. See, e.g., Twentieth Century Fox Film Corp. v. Entm't Distrib., 429 F.3d 869, 876 (9th Cir. 2005) (applying "work for hire" doctrine of 1909 Act where allegedly infringed work was published before the effective date of the 1976 Act, even though alleged act of infringement occurred after the effective date of the 1976 Act); Roth v. Pritikin, 710 F.2d 934, 938 (2d Cir. 1983) ("Section 301 [of the 1976 Act] does not . . . purport to determine who holds a copyright for works created before January 1978. It merely clarifies the rights of individuals owning copyrights on that date, whomever they may be."). 
textual commitment to preserve ownership status is clearly preferable. ${ }^{78}$

\section{Remedies}

Federal copyright law provides that an infringer of copyright is liable for the actual damages suffered by the copyright owner, as well as any profits of the infringer attributable to the infringement to the extent they have not been taken into account in determining actual damages. ${ }^{79}$ In addition, a prevailing plaintiff who has registered his copyright in a timely manner is eligible to instead opt for statutory damages ${ }^{80}$ Statutory damages can range from $\$ 750$ to $\$ 30,000$ per work, and up to $\$ 150,000$ per work if the infringement was committed willfully. ${ }^{81}$ While actual or compensatory damages are also available under state law, statutory damages are not. ${ }^{82}$ Instead, state laws may permit the award of punitive or exemplary damages, ${ }^{83}$ an avenue not permitted under federal copyright law. ${ }^{84}$

Another remedy available under federal law to right holders who have timely registered their works is an award of costs and attorney's fees at the court's discretion. ${ }^{85}$ There is no corollary under state law.

\section{Formalities}

In order to bring an action for copyright infringement of a work of U.S. origin, the right holder must first register the work in the United States Copyright Office. ${ }^{86}$

78. Similarly, provision would have to be made to ensure that owners of rights in pre-1972 sound recordings are not disadvantaged for failing to comply with federal priority-of-transfer rules prior to federalization. See 17 U.S.C. § 205 (2012); infra note 106 and accompanying text.

79. It also provides for remedies other than damages: a court may enter a preliminary or permanent injunction against continuing infringement and may order impoundment and reasonable disposition of infringing articles. 17 U.S.C. $\$ \S 502,503$.

80. The copyright owner may elect statutory damages at any time before final judgment. 17 U.S.C. $\S 504(\mathrm{c})(1)$. For what constitutes "timely" registration for this purpose, see the discussion of formalities infra Part III.B.6.

81. 17 U.S.C. $\S 504(\mathrm{c})(1)-(2)$. The court may reduce the award to $\$ 200$ per work if the infringement was innocent, and must remit statutory damages entirely when the infringement was done by an employee or agent of a nonprofit library, archive or educational institution who believed and had reason to believe the use was a fair use. $I d$. $\S 504(\mathrm{c})(2)$. There is a similar provision with respect to certain nonprofit activities of a public broadcasting entity. Id.

82. See, e.g., A\&M Records, Inc. v. Heilman, 142 Cal. Rptr. 390, 399-400 (Cal. Ct. App. 1977) (defendant may be assessed damages for unfair competition); GAI Audio of N.Y., Inc. v. Columbia Broad. Sys., Inc., 340 A.2d 736, 753-54 (Md. Ct. Spec. App. 1975) (awarding compensatory and punitive damages for record piracy).

83. See, e.g., Bridgeport Music, Inc. v. Justin Combs Publ'g, 507 F.3d 470, 490 (6th Cir. 2007) (awarding \$3.5 million in punitive damages for unlicensed sampling of a recording deemed unconstitutionally excessive; remanding case to district court with instruction to apply a punitive to compensatory damages ratio of 2:1 or 1:1); U.S. Sporting Prods., Inc. v. Johnny Stewart Game Calls, Inc., 865 S.W.2d 214, 223 (Tex. Ct. App. 1993) (affirming punitive damages award for misappropriation of a sound recording); see 4 NIMMER ON COPYRIGHT, supra note 10, § 14.02[C][2].

84. See, e.g., On Davis v. The Gap, Inc., 246 F.3d 152, 172 (2d Cir. 2001); Hays v. Sony Corp. of Am., 847 F.2d 412, 415 (7th Cir. 1988).

85. 17 U.S.C. $\$ 505$.

86. 17 U.S.C. $\S 411$ (a). To register, the claimant must file an application for registration, pay the 
Thus, registration is a condition of suit, but registration may be made any time before suit is filed. If, however, a right holder wants to ensure the availability of statutory damages or attorney's fees, registration must be made before the infringement commences or, in the case of a published work, within three months of first publication. ${ }^{87}$ State laws have no comparable registration requirements.

\section{Potential Plaintiffs Who Might Claim a Constitutional DEPRIVATION}

Having briefly considered how current state law rights differ from the rights that would be available under federalized protection for pre-1972 sound recordings, this Article will now identify the possible stakeholders who might claim a constitutional deprivation. ${ }^{88}$

The first group is comprised of right holders whose sound recordings would have abbreviated terms of protection under federal law. These right holders fall, in turn, into two categories. The first are those who would be entitled to federal copyright protection until 2067 provided that they meet the extended term requirements. ${ }^{89}$ Such right holders might attempt to claim that those requirements unconstitutionally burden their rights in pre-1972 sound recordings. The second overlapping category of right holders are those whose rights will be truncated regardless of whether they meet the extended term requirements: specifically, owners of sound recordings published prior to 1923 whose recordings would, at most, receive only twenty-five years of federal protection. ${ }^{90}$

The second group is comprised of right holders who might argue that the federal rights and remedies are substantively inferior to a significant enough extent that their application would violate due process or constitute a taking. Among the claims that might conceivably be raised are the financial and logistical demands of

registration fee and deposit a copy or copies of the work. 17 U.S.C. $\S 408$ (a)-(b). Effective May 1, 2014 , the fee for online registration will be $\$ 55$, unless it is an online registration of a single work (not a work made for hire) by an individual author, in which case it will be $\$ 35$. Paper filings will have an $\$ 85$ fee. See Copyright Office Fees, U.S. COPYRIGHT OFFICE, http://www.copyright.gov/fls/s104_2014.pdf (last visited Apr. 11, 2014). The effective date of registration is the date that the application, fee and deposit copies have all been received by the Copyright Office. 17 U.S.C. $\S 410$ (d).

87. 17 U.S.C. $\S 412$. In other words, if a work is published and then infringed, the right holder will be entitled to statutory damages even if the registration is made after the infringement commences, as long as the effective date of the registration is within three months of first publication. See id. The statute also provides for "preregistration" of certain unpublished works being prepared for commercial distribution, including sound recordings, that have a history of infringement prior to commercial distribution. 17 U.S.C. $\S 408(\mathrm{f})$.

88. The Tucker Act provides that the Court of Federal Claims has jurisdiction over claims against the United States "founded either upon the Constitution, or any Act of Congress or any regulation of an executive department, or upon any express or implied contract with the United States, or for liquidated or unliquidated damages in cases not sounding in tort." 28 U.S.C. § 1491(a)(1) (2012); accord Ruckelshaus v. Monsanto Co., 467 U.S. 986, 1016 (1984) ("Generally, an individual claiming that the United States has taken his property can seek just compensation under the Tucker Act, 28 U.S.C. § 1491.").

89. See supra Part II.

90. See supra Part II. 
timely registering the copyrights in pre-1972 sound recordings, a prerequisite to statutory damages under federal copyright law, ${ }^{91}$ and relatedly, the loss of the potential for punitive damages under state law.

The third group is comprised of users of pre-1972 sound recordings whose prefederalization activities arguably did not violate state laws but may, upon federalization, violate the ambit of federal law protections accorded to right holders. ${ }^{92}$

Accordingly, we now consider the merits of these claims.

\section{RETROACTIVITY}

Congressional extension of federal protection would necessarily entail a concomitant revocation of the state law regime that currently governs pre-1972 sound recordings. The concerns raised by a revocation of these protections did not arise when Congress first extended federal copyright protection to sound recordings in 1971. As discussed earlier, that legislation operated prospectively, providing an exclusive federal right to reproduce and distribute sound recordings "fixed, published, and copyrighted on and after" February 15, 1972. ${ }^{93}$

\section{A. General Considerations}

As a starting point, "[r]etroactivity is not favored in the law." "Elementary considerations of fairness dictate that individuals should have an opportunity to know what the law is and to conform their conduct accordingly; settled expectations should not be lightly disrupted." $" 95$ Thus, "[s]tatutes are disfavored as retroactive when their application 'would impair rights a party possessed when he acted, increase a party's liability for past conduct, or impose new duties with respect to transactions already completed." ${ }^{\prime 96}$ Determining whether a statute

91. Timely registration is also required for an award of attorney's fees to a prevailing plaintiff in a copyright action, and registration is required as a condition of suit for U.S. works. 17 U.S.C. $\S \S$ 411(a), 412.

92. See, e.g., Abigail Phillips, Elec. Frontier Found., Comments of EFF in Response to Notice of Inquiry $13-15$, in U.S. COPYRIGHT OFFICE, COMMENTS REGARDING FEDERAL COPYRIGHT PROTECTION OF SOUND RECORDINGS FIXED BEFORE FEB. 15, 1972 (2011), available at http://www.copyright.gov/ docs/sound/comments/initial/. Certain users (webcasters and on-demand streamers) would, in the wake of the federalizing legislation, have to pay a performance royalty under 17 U.S.C. $\S \S 112$ and 114 in connection with the digital transmission of pre-1972 sound recordings. It seems doubtful that the imposition of royalties (which right holders in post-1972 sound recordings already pay) would raise cognizable Fifth Amendment problems.

93. See Sound Recording Amendment, Pub. L. No. 92-140, § 3, 85 Stat. 391, 392 (1971) (providing, in pertinent part, an effective date of February 15, 1972).

94. Bowen v. Georgetown Univ. Hosp., 488 U.S. 204, 208 (1988).

95. Landgraf v. USI Film Prods., 511 U.S. 244, 265 (1994); see also Republic of Austria v. Altmann, 541 U.S. 677, 696 (2004) ("The aim of the presumption [against retroactivity] is to avoid unnecessary post hoc changes to legal rules on which parties relied in shaping their primary conduct.").

96. Fernandez-Vargas v. Gonzales, 548 U.S. 30, 37 (2006) (quoting Landgraf, 511 U.S. at 280); see also Altmann, 541 U.S. at 693 ("[R]etroactive statutes may upset settled expectations by 'tak[ing] away or impair[ing] vested rights acquired under existing laws, or creat[ing] a new obligation, 
operates retroactively, however, is no "simple or mechanical task."97 On the one hand, the Supreme Court has framed the inquiry as whether the new statute "attaches new legal consequences to events completed before its enactment."98 On the other hand, the Court has also said that a statute is not retroactive "merely because it is applied in a case arising from conduct antedating the statute's enactment or upsets expectations based in prior law." 99

Fortunately, it is not necessary to address in the abstract the question of the potential retroactive effects of any federalizing legislation. Where Congress is clear as to a statute's reach, the statute may operate "retroactively" as long as it does not run afoul of the specific anti-retroactivity restrictions imposed by the Constitution. ${ }^{100}$ The reason for this is that

[r] etroactivity provisions often serve entirely benign and legitimate purposes, whether to respond to emergencies, to correct mistakes, . . . or simply to give comprehensive effect to a new law Congress considers salutary. However, a requirement that Congress first make its intention clear helps ensure that Congress itself has determined that the benefits of retroactivity outweigh the potential for disruption or unfairness. ${ }^{101}$

Therefore, if Congress enacts federalizing legislation with a clear temporal reach, it will only remain to consider constitutional barriers to its enactment.

\section{B. APPLiCATIONS to FEDERALIZING LEGISLATION}

This Article first identifies lines that Congress could draw clearly and that would minimize any retroactive effect of the federalizing legislation. Accordingly, it

impos[ing] a new duty, or attach[ing] a new disability, in respect to transactions or considerations already past." (citations omitted) (alterations in original)).

97. See Landgraf, 511 U.S. at 268; id. at 270 ("Any test of retroactivity will leave room for disagreement in hard cases, and is unlikely to classify . . . legal changes with perfect philosophical clarity."); see also Jill E. Fisch, Retroactivity and Legal Change: An Equilibrium Approach, 110 HARV. L. REV. 1055, 1072-73 (1997) (articulating an approach to retroactivity that requires less of a binary determination and more of a classification by degree of effect). Retroactivity concerns may arise when a court is asked to apply a new statutory provision to pending proceedings. See, e.g., Martin v. Hadix, 527 U.S. 343, 347 (1999); Landgraf, 511 U.S. at 249-50. They may also arise when a court must decide whether to apply a statute to conduct that allegedly pre-dates the effective date of the statute. See, e.g., Vartelas v. Holder, 132 S. Ct. 1479, 1484 (2012); Fernandez-Vargas, 548 U.S. at 45-47.

98. Landgraf, 511 U.S. at 270; accord Vartelas, 132 S. Ct. at 1491.

99. Landgraf, 511 U.S. at 269 (citation omitted).

100. INS v. St. Cyr, 533 U.S. 289, 316 (2001) ("Despite the dangers inherent in retroactive legislation, it is beyond dispute that, within constitutional limits, Congress has the power to enact laws with retrospective effect. A statute may not be applied retroactively, however, absent a clear indication from Congress that it intended such a result." (citation omitted)); Landgraf, 511 U.S. at 266 (identifying as the relevant provisions: the Ex Post Facto Clauses, the Contracts Clause, the Takings Clause, the prohibitions against Bills of Attainder and the Due Process Clause).

101. Landgraf, 511 U.S. at 267-68. Where Congress has not made the reach of the legislation clear, the Supreme Court has instituted a judicial presumption against giving legislation retroactive effect. See id. It has applied this presumption against statutory retroactivity most frequently to "new provisions affecting contractual or property rights, matters in which predictability and stability are of prime importance." Id. at 271. 
assumes that a further constitutional analysis is not warranted with respect to the following topics.

First, and critically, federalizing legislation should make explicit that it would not effect a change in ownership. Second, Congress should make clear that federalizing legislation applies only to cases commenced after the effective date of the legislation. Even with respect to litigation commenced after the statute's effective date, Congress should make clear that federal copyright law would be applicable only to infringement-related activities in connection with pre-1972 sound recordings that occur on or after the effective date. That is, it should be modeled after the 1976 Copyright Act, which provided that federal law would not annul or limit any state law rights or remedies with respect to "any cause of action arising from undertakings commenced before January 1, 1978." 102 Accordingly, a federal action for copyright infringement of pre-1972 sound recordings should not reach allegedly infringing activities that occur prior to the effective date.

Similarly, federal limitations and exceptions should be applied only to postfederalization activities. Thus, a fair use defense to alleged infringement occurring before the statute's effective date should be available only to the extent it would have been available under the applicable state law. Likewise, webcasting a pre1972 sound recording would be subject to the digital audio performance right under 17 U.S.C. $§ 114$, including the statutory license, only if done after the effective date. $^{103}$

There are many other ways in which Congress could minimize any retroactive effect. In brief, the federalizing legislation's termination provisions should be made applicable only to post-federalization grants. ${ }^{104}$ Right holders should be given a reasonable opportunity to register their works. Likewise, the term "infringement" in the federal provisions concerning statutory damages and attorney's fees ${ }^{105}$ should be defined to mean infringement under federal law. This would prevent a right holder from being foreclosed from seeking those remedies for failure to register before any unauthorized reproduction or distribution commenced, even though the work was not then eligible for federal copyright registration. By the same token, federal statutory damages should apply only to infringing conduct that occurred after federalization to avoid attaching new

102. 17 U.S.C. $§ 301(b)(2)$. In general, "undertakings" has referred to "infringement." See infra note 295 and accompanying text.

103. See Golan v. Gonzales, No. Civ.01-B-1854(BNB), 2005 WL 914754, at*17 (D. Colo. Apr. 20, 2005) (holding URAA Section 514 not retroactive because while it "grants many retroactive benefits to authors, it does not impose retroactive burdens upon the plaintiffs. This is because Section 514 does not impose upon the plaintiffs liability for, or new duties as a result of, their past conduct. Nor does Section 514 impair rights that the plaintiffs possessed when they acted. In short, Section 514 does not alter the legal consequences of the plaintiffs' completed acts" (citations omitted)).

104. See Copyright OfFice Report, supra note 5, at ix. Federal law provides for the possibility of terminating a grant made by the author after thirty-five years, to allow the author or her heirs to renegotiate a grant that may have been made when the value of the work was not known. See 17 U.S.C. $\S 203$ (a). Certain grants with respect to works published prior to January 1, 1978 can be terminated under different conditions. See id. § 304(c)-(d).

105. Id. $\S 412$. 
consequences to prior acts. ${ }^{106}$

Finally, under federal law, it is criminal infringement to "willfully" infringe a copyright "for purposes of commercial advantage or private financial gain" or to make copies with a total retail value of more than $\$ 1,000$ within a 180-day period. $^{107}$ State criminal laws generally require proof that the infringing activity was done for commercial advantage and do not provide that such intent can be imputed by the volume or dollar value of the copies made. ${ }^{108}$ To ensure the federalizing legislation has no retroactive effect in violation of the Ex Post Facto Clause, ${ }^{109}$ it should be made clear that the volume or retail value of copies illegally sold prior to the effective date of federalization would not be considered in determining federal criminal liability. ${ }^{110}$

The following areas comprise the central focus of the remainder of this Article:

- Foreshortened term of protection. For sound recordings published prior to 1923, right holders would have to relinquish years of state law copyright ownership because they would be eligible for a maximum of twenty-five additional years of protection. (Right holders in later or unpublished recordings, if they took no action, would also face such forced relinquishment.)

- Obligation to make the work reasonably available and to file a notice in the Copyright Office. To meet the extended term requirements, right holders of sound recordings would have to file notices in the Copyright Office and make the recordings available. These obligations might conceivably entail financial or other hardships.

- Registration. Right holders would have to expend funds to register their recordings with the Copyright Office to qualify for statutory damages or attorney's fees, or to bring an infringement action if the recording is a United States work.

- Substitution of federal rights and remedies. Federal rights would displace

106. The priority of transfer rules in $\S 205$ (d) should be amended to give right holders a reasonable opportunity to register and record past transfers in the Copyright Office. Section 205(d) provides that where there are conflicting transfers, priority is given to the one executed first if it is recorded in the Copyright Office within one month after its execution (or within two months if it was executed outside the United States). 17 U.S.C. § 205(c).

107. 17 U.S.C. $\$ 505$.

108. See, e.g., Fla. Stat. § 540.11 (2012); N.J. Stat. Ann. 2C:21-21(c) (West 2012). The volume sold may, however, affect the penalty. See, e.g., FLA. STAT. § 540.11(2)(b) (2012); N.Y. PENAL CODE $§ 275.05$ (McKinney 2012). To the extent that right holders are dissatisfied with the displacement of state criminal law by federal criminal law, the Supreme Court has held that the "benefit that a third party may receive from having someone else arrested for a crime generally does not trigger protections under the Due Process Clause, neither in its procedural nor in its 'substantive' manifestations." Town of Castle Rock v. Gonzales, 545 U.S. 748, 768 (2005).

109. U.S. CONST. art. I, § 9, cl. 3.

110. To avoid complicated issues concerning the copyright status of musical or other works embodied only in a phonorecord prior to when sound recordings were eligible for federal copyright, and in particular, concerning whether those underlying works should be considered to have been "fixed," we recommend that the federalizing legislation provide that it is not intended to affect the copyright status of any underlying work. 
state rights; statutory damages claims would replace state punitive damages claims.

- Restrictions on users. Uses currently being made under state law might be restricted if federal law is applied.

With respect to these issues, we also assume that Congress could draft the operative language to make clear the activities to which it applies. But, anticipating the argument that such aspects work a constitutionally impermissible retroactive change, we spend the remainder of the Article considering whether these aspects would violate the two relevant constitutional provisions: the Takings Clause and the Due Process Clause.

\section{THE FIFTH AMENDMENT ANAL YSIS}

The Fifth Amendment protects property against incursions by the federal government in at least two ways. It ensures both that "[n]o person shall . . be deprived of . . . property, without due process of law" and that "private property [shall not] be taken for public use, without just compensation." 111 Whereas the Takings Clause "presupposes that the government has acted in pursuit of a valid public purpose," the Due Process Clause addresses the anterior question of whether a regulation "fails to serve any legitimate governmental objective." 112 The relationship between takings and due process analyses is complex. ${ }^{113}$ Indeed, in the copyright context, the plaintiffs in recent litigation over the removal of certain foreign works from the public domain challenged the operative federal statute on the ground of substantive due process, rather than takings. ${ }^{114}$ Accordingly, both

111. U.S. CONST. amend. V. The Takings Clause applies to the states by way of the Fourteenth Amendment. See Kelo v. City of New London, 545 U.S. 469, 472 n.1 (2005) (citing Chicago, B. \& Q.R. Co. v. Chicago, 166 U.S. 226 (1897)). Cases addressing takings challenges to federal activities routinely rely upon case law addressing takings challenges to state activities. See, e.g., Hodel v. Irving, 481 U.S. 704, 713-14 (1987). Accordingly, in this Article, we rely upon both lines of precedent when analyzing possible takings challenges to the federalizing legislation.

Similarly, the texts of the Fifth and Fourteenth Amendment Due Process Clauses are "substantively identical." Thomas W. Merrill, The Landscape of Constitutional Property, 86 VA. L. REV. 885, $886 \mathrm{n} .1$ (2000). In considering due process challenges to economic legislation, the Supreme Court has applied the same principles to state and federal legislation. See, e.g., Gen. Motors Corp. v. Romein, 503 U.S. 181, 191 (1992); Pension Benefit Guar. Corp. v. R.A. Gray \& Co., 467 U.S. 717, 729-30 (1984). This Article also draws upon both lines of precedent.

112. Lingle v. Chevron U.S.A. Inc., 544 U.S. 528, $542-43$ (2005); see also id. at 543 (noting that the question of a regulation's underlying validity — or whether the government has acted so arbitrarily as to violate due process - is "logically prior to and distinct from the question whether a regulation effects a taking"); id. at 548 (Kennedy, J., concurring); E. Enter. v. Apfel, 524 U.S. 498, 539-40 (1998) (Kennedy, J., concurring in the judgment and dissenting in part).

113. See, e.g., Stop the Beach Renourishment, Inc. v. Fla. Dep't of Envtl. Prot., 130 S. Ct. 2592, 2606 (2010) (plurality opinion) (identifying problems "with using Substantive Due Process to do the work of the Takings Clause"). Justice Kennedy, joined by Justice Sotomayor, disagreed with the need to extend takings and emphasized that the "Court has long recognized that property regulations can be invalidated under the Due Process Clause." Id. at 2614 (Kennedy, J., concurring in part and concurring in the judgment) (citations omitted).

114. Golan v. Holder, 132 S. Ct. 873, 883 n.15 (2012) (noting the claim in passing); Golan v. Gonzales, No. Civ.01-B-1854(BNB), 2005 WL 914754, at*17-18 (D. Colo. Apr. 20, 2005) (granting 
clauses will be considered here.

To begin with, both clauses target the diminishment of property interests. ${ }^{115}$ Many scholars have addressed the overarching question of the extent to which "intellectual property" should be characterized, both analytically and rhetorically, as a species of "property." 116 Among other things, they have considered how the theoretical justifications for property rights apply to intellectual property, ${ }^{117}$ whether intellectual property rights are more appropriately enforced through property rules or through liability rules ${ }^{118}$ and how the digital era should shape any conception of intellectual property rights as a form of property rights. ${ }^{119}$ The very decision by a court to apply the Takings and Due Process Clauses to a stateprotected copyright or copyright-like interest could be viewed as a momentous conceptual move to entrench the treatment of intellectual property as property.

the government summary judgment on the substantive due process claim). For further discussion of this case, see infra Part V.F.

115. The property interests protected by each clause are not necessarily coextensive. See, e.g., E. Enters. v. Apfel, 524 U.S. 498, 557 (1998) (Breyer, J., dissenting); accord Merrill, supra note 111, at 889 ("After College Savings Bank, one thing seems reasonably clear: Parties seeking to protect an economic interest under the Due Process or Takings Clauses, whether advancing a procedural or a substantive claim, must be prepared to demonstrate that their interest is 'property."'); Carlos Manuel Vázquez, What Is Eleventh Amendment Immunity?, 106 YALE L.J. 1683, 1745-46 n.281 (1997); Olivia A. Radin, Note, Rights as Property, 104 ColuM. L. REV. 1315, 1319 \& n.23 (2004).

116. The literature is too vast to set forth comprehensively. See, e.g., NEIL WeINSTOCK NETANEL, COPYRIGHT'S PARADOX 6-7 (2008) (critiquing conception of copyright as full-fledged Blackstonian property right); Tom W. Bell, Copyright as Intellectual Privilege, 58 SYRACUSE L. REV. 523, 524 (2008) (arguing for copyright as privilege rather than property); Mark A. Lemley, Romantic Authorship and the Rhetoric of Property, 75 TEX. L. REV. 873, 895-897 (1997) (reviewing JAMES BOYLE, Shamans, SOFTwARE, AND SPleENS: LAW AND THE CONSTRUCTION OF THE INFORMATION SOCIETY (1996)) (contending that "the rhetoric and economic theory of real property are increasingly dominating the discourse and conclusions of the very different world of intellectual property"); Henry E. Smith, Intellectual Property as Property: Delineating Entitlements in Information, 116 YALE L.J. 1742, 1744 (2007) ("At the core of controversies over the correct scope of intellectual property lie grave doubts about whether intellectual property is property.").

117. See, e.g., Justin Hughes, The Philosophy of Intellectual Property, 77 GEO. L.J. 287, 290 (1988) (arguing that "the labor and personality theories together exhaust the set of morally acceptable justifications of intellectual property”); Tom G. Palmer, Are Patents and Copyrights Morally Justified? The Philosophy of Property Rights and Ideal Objects, 13 HARV. J.L. \& PUB. POL'Y 817, 820-21 (questioning whether patents and copyrights are "legitimate forms of property at all") (1990); Alfred C. Yen, Restoring the Natural Law: Copyright as Labor and Possession, 51 OHIO ST. L.J. 517, 547 (1990) (calling for the development of a "natural law copyright jurisprudence").

118. See, e.g., Dane S. Ciolino \& Erin A. Donelon, Questioning Strict Liability in Copyright, 54 RUtGers L. REV. 351, 364 (2002) ("Although 'intellectual property' has long been compared to 'property,' and 'infringement of copyright' compared to 'trespass to realty,' these analogies are problematic ...." (footnotes omitted)); Daniel A. Crane, Intellectual Liability, 88 TEX. L. REV. 253, 255-256 (2009) (arguing for a richer analysis of the "property-liability debate"); Mark A. Lemley \& Philip J. Weiser, Should Property or Liability Rules Govern Information?, 85 TEX. L. REV. 783, 784-785 (2007) (identifying benefits of liability-based relief where injunctive relief cannot be narrowly tailored); Robert P. Merges, Of Property Rules, Coase, and Intellectual Property, 94 COLUM. L. REV. 2655, 2664-67 (1994) (describing intellectual property disputes as largely compatible with a property rules framework).

119. See, e.g., Adam Mossoff, Is Copyright Property?, 42 SAN Diego L. REV. 29, 42-43 (2005) (favoring retained, and evolving, notion of intellectual property rights as property rights). 
While not intending to take a stance on the important, broader question of intellectual property as property vel non, we think it is likely that the Court would hold the interests at stake here to constitute property for purposes of the Due Process and Takings Clauses. ${ }^{120}$

In Ruckelshaus v. Monsanto Co., the Supreme Court was faced with a takings claim that designated trade secrets as the relevant property interest. ${ }^{121}$ The Court accepted plaintiff Monsanto's claim that the data it had submitted to the Environmental Protection Agency (EPA) under the requirements of the Federal Insecticide, Fungicide, and Rodenticide Act (FIFRA) was property, in the form of a trade secret, under Missouri state law. ${ }^{122}$ As with trade secrets, pre-1972 copyright interests are assignable, can form the res of a trust, and pass to a trustee in bankruptcy. ${ }^{123}$ Later courts in other settings have also signaled that they view intellectual property rights, including copyrights, as property for purposes of Takings Clause protection. ${ }^{124}$

In the present context, courts defining the property right in a pre-1972 sound recording would look to the applicable state law, ${ }^{125}$ since it is well established that

120. See Coll. Sav. Bank v. Fla. Prepaid Postsecondary Educ. Expense Bd., 527 U.S. 666, 673 (1999) ("The Lanham Act may well contain provisions that protect constitutionally cognizable property interests - notably, its provisions dealing with infringement of trademarks, which are the 'property' of the owner because he can exclude others from using them."); $i d$. at 675 (noting that the "assets of a business (including its good will) unquestionably are property" within the scope of the Fourteenth Amendment's Due Process Clause); Fla. Prepaid Postsecondary Educ. Expense Bd. v. Coll. Sav. Bank, 527 U.S. 627, 642 (1999) (determining that a patent is property protected by the Fourteenth Amendment's Due Process Clause); accord Roth v. Pritikin, 710 F.2d 934, 939 (2d Cir. 1983) ("An interest in a copyright is a property right protected by the due process and just compensation clauses of the Constitution."). While the Court in College Savings Bank warned against the dangers of using unfair competition law to define constitutionally protected property interests, the state law interests at stake in our context manifest the approved-of hallmark of a right to exclude. 527 U.S. at $673-74$.

121. Ruckelshaus v. Monsanto Co., 467 U.S. 986, 1000-01 (1984).

122. Id. at 1001-05 (1984). In addition, while disclaiming the necessity of doing so, the Court found support for the "general perception of [trade secrets'] property-like nature" in Congress' characterization of trade secrets in the legislative history. $I d$. at $1002,1003 \mathrm{n} .8$.

123. See id. at 1002 (limning characteristics of trade secrets that made them protectable property interests under state law and under the Takings Clause).

124. In a split decision, five Supreme Court Justices agreed that intellectual property is within the purview of the Takings Clause. E. Enter. v. Apfel, 524 U.S. 498, 540 (1998) (Kennedy, J., concurring in the judgment and dissenting in part); id. at 554 (Breyer, J., dissenting); see also Lane v. First Nat'l Bank of Bos., 871 F.2d 166, 174 (1st Cir. 1989) (stating that "a copyright is property" and suggesting that a Takings Clause claim might provide a remedy); Roth v. Pritikin, 710 F.2d 934, 939 (2d Cir. 1983) (“An interest in a copyright is a property right protected by the due process and just compensation clauses of the Constitution."). But see Davida H. Isaacs, Not All Property is Created Equal: Why Modern Courts Resist Applying the Takings Clause to Patents, and Why They Are Right to Do So, 15 GEO. MASON L. REV. 1, 5-6, 28-29 (2007) (arguing that a patent is a federally granted benefit, and that the categorization of a patent as "property" does not necessitate the protections of the Takings Clause).

125. For the purposes of this analysis, state law interests are referred to collectively as "state law copyrights," even though many states protect published pre-1972 sound recordings through unfair competition and misappropriation causes of action rather than through a tort denominated "common law copyright." All of these state law claims have in common the right to exclude others from certain uses. However, the scope of the right holder's interest varies. See generally Jaszi Report, supra note 21, at 9-22. Accordingly, the claim to have property cognizable under the Constitution may be stronger in some states than in others. 
"[p]roperty interests . . . . are created and their dimensions . . . defined by existing rules or understandings that stem from an independent source such as state law." 126 Thus, a court might consider the law of the jurisdiction where the sound recording was recorded or where the right holder is located. ${ }^{127}$ Notably, even the uncertain or minimal economic value of the state law copyrights in older or more esoteric pre1972 sound recordings would not necessarily defeat a property-based claim. ${ }^{128}$ Accordingly, the interests affected by a revocation of state law protections would likely constitute "property" for constitutional purposes. ${ }^{129}$ At the very least, since we cannot rule out that they would constitute property under the law of some state, we assume due process and takings protections would apply. ${ }^{130}$

\section{A. FrameWork FOR ANALySIS}

Federalizing legislation for pre-1972 sound recordings falls easily under the heading of economic legislation. It is well established that laws "adjusting the burdens and benefits of economic life come to the Court with a presumption of constitutionality," and that one complaining of a due process violation must "establish that the legislature has acted in an arbitrary and irrational way." 131 Moreover, such a legislative adjustment is "not unlawful solely because it upsets

126. Webb's Fabulous Pharmacies, Inc. v. Beckwith, 449 U.S. 155, 161 (1980) (quoting Board of Regents v. Roth, 408 U.S. 564, 577 (1972) (internal quotation marks omitted)); $c f$. Stop the Beach Renourishment, Inc. v. Fla. Dep't of Envtl. Prot., 130 S. Ct. 2592, 2612 (2010) ("The Takings Clause only protects property rights as they are established under state law, not as they might have been established or ought to have been established.").

127. Recent case law reflects the difficulties inherent in identifying the situs of injury for purposes of personal jurisdiction in the Internet age. See Penguin Grp. (USA) Inc. v. Am. Buddha, 946 N.E.2d 159, 163-64 (N.Y. 2011); see also Penguin Grp. (USA) Inc. v. Am. Buddha, 609 F.3d 30, 32 (2d Cir. 2010).

128. See Phillips v. Wash. Legal Found., 524 U.S. 156, 170 (1998) ("While the interest income at issue here may have no economically realizable value to its owner, possession, control, and disposition are nonetheless valuable rights that inhere in the property."); $i d$. at 172 (holding that the "interest income generated by funds held in IOLTA accounts is the "private property' of the owner of the principal").

129. See Thomas F. Cotter, Do Federal Uses of Intellectual Property Implicate the Fifth Amendment?, 50 FLA. L. REV. 529, 566-67 (1998) (arguing similarly in the case of copyrights, but distinguishing "rights recognized under the federal law of unfair competition," such as "the right to be free from dilution," as more difficult to classify as property).

130. Clearly, if the Court were to decide otherwise, then no further constitutional analysis would be warranted. In Dowling v. United States, the Supreme Court stated that "[t]he copyright owner . . holds no ordinary chattel," and refused to deem bootlegged phonorecords "stolen" "goods" under 18 U.S.C. § 2314. 473 U.S. 207, 216 (1985). That case is distinguishable, however, on three grounds: (1) the criminal nature of the statute drove the Court to apply a "narrow" construction of its reach; (2) the present concern is whether right holders have sufficient property-based interests under state law, not whether they own "goods" or "wares" and (3) in Ruckelshaus v. Monsanto, the Court did deem trade secrets as property protected under the Takings Clause. 467 U.S. 986, 1003-04 (1984). Thus, even if the nature of copyright ownership is "distinct" from other forms of property ownership, Dowling, 473 U.S. at 217, it is likely that stakeholders in this context would raise colorable claims of a deprivation of constitutionally protected property. We thank Professor Irina Manta for helpful discussion on this point.

131. Usery v. Turner Elkhorn Mining Co., 428 U.S. 1, 15 (1976) (citing Ferguson v. Skrupa, 372 U.S. 726 (1963); Williamson v. Lee Optical Co., 348 U.S. 483, 487-88 (1955)). 
otherwise settled expectations."132 The Court long ago proclaimed that "[n]o person has a vested interest in any rule of law, entitling him to insist that it shall remain unchanged for his benefit."133 Rather, the retroactive and prospective aspects of economic legislation simply must meet the due process requirement of "a legitimate legislative purpose furthered by rational means."134 Demonstrating that they do not meet this requirement is a high burden, and courts are reluctant to find violations. ${ }^{135}$ Indeed, the Court has gone so far as to say that a "legislative determination provides all the process that is due."136

As a general proposition, it is indisputable that Congress legitimately may determine that the current patchwork of state law protections does not adequately "promote the [p]rogress of [s]cience and useful [a]rts" 137 and that a unified federal scheme would better do so. Indeed, as discussed above, Congress made that legislative determination when, in 1976, it federalized copyright protectionwithout repercussions - for unpublished works that had already been created. ${ }^{138}$ That aspect of the 1976 Copyright Act ended what had been perpetual protection for unpublished works. The House Report concluded that this substitution of federal rights for state rights was "fully in harmony with the constitutional requirements of due process" as long as Congress provided a reasonable period of federal protection for those works. ${ }^{139}$ Likewise, the 1976 Act capped what had been perpetual protection for pre-1972 sound recordings, providing a hard end date (ultimately, 2067) for state law protections. ${ }^{140}$

Both of these changes - each arguably more drastic than those currently under consideration, since they terminated what had been perpetual protection of works under state law-were enacted without legal challenge. Thus, there is strong precedent for allowing Congress to amend the legislative scheme if it concludes,

132. Usery, 428 U.S. at 16.

133. N.Y. Cent. R.R. Co. v. White, 243 U.S. 188, 198 (1917) (rejecting due process challenge to state workers' compensation legislation that abrogated common law rules); $c f$. LON L. FULLER, THE MORALITY OF LAW 53, 60 (rev. ed. 1969) (describing the "ossifi[cation]" of law that would occur if people were "secure[d] against any change in legal rules").

134. Gen. Motors Corp. v. Romein, 503 U.S. 181, 191 (1992) (considering a Michigan statute but invoking same principles as federal due process analysis); see also Lingle v. Chevron U.S.A. Inc., 544 U.S. 528, 542 (2005) ("[A] regulation that fails to serve any legitimate governmental objective may be so arbitrary or irrational that it runs afoul of the Due Process Clause."); Pension Benefit Guar. Corp. v. R.A. Gray \& Co., 467 U.S. 717, 729-30 (1984) (requiring a "showing that the retroactive application of the legislation is itself justified by a rational legislative purpose").

135. Lingle, 544 U.S. at 545 ("[W]e have long eschewed . . . heightened scrutiny when addressing substantive due process challenges to government regulation."); accord Fisch, supra note 97, at 1074 (noting that "the Court has not subjected retroactive legislation to close due process scrutiny," only rational basis scrutiny). But see Lingle, 544 U.S. at 548 (Kennedy, J., concurring) (noting "the possibility that a regulation might be so arbitrary or irrational as to violate due process").

136. Logan v. Zimmerman Brush Co., 455 U.S. 422, 433 (1982).

137. U.S. ConST. art. I, § 8, cl. 8; accord Fla. Prepaid Postsecondary Educ. Expense Bd. v. Coll. Sav. Bank, 527 U.S. 627, 645 (1999) ("The need for uniformity in the construction of patent law is undoubtedly important, [and] that is a factor which belongs to the Article I patent-power calculus ....”).

138. 17 U.S.C. § 303(a) (2012); see discussion supra Part I.

139. See H.R. REP. No. 94-1476, at 139 (1976).

140. 17 U.S.C. $\S 301(\mathrm{c})$. 
for example, that the patchwork scheme of state law protections makes users reluctant to engage in socially beneficial activities, such as preservation, scholarship and teaching. ${ }^{141}$ The devil, of course, is in the details, and it remains to be considered whether legislation addressing the most contentious areas identified above would pass muster.

The Takings Clause "does not prohibit the taking of private property, but instead places a condition on the exercise of that power."142 Thus, it is not designed to "limit the governmental interference with property rights per se, but rather to secure compensation in the event of otherwise proper interference amounting to a taking." 143 The purpose of this provision, the Court has said, is to prevent the government from "forcing some people alone to bear public burdens which, in all fairness and justice, should be borne by the public as a whole." $" 144$ The analysis turns on at least four considerations: (1) whether the subject matter at issue is a protectable private property interest; (2) whether a taking of the property has occurred; (3) if a taking has occurred, whether it is for a public use; (4) whether just compensation has been provided. ${ }^{145}$ With respect to the first, as discussed above, It is assumed that courts would deem the property interests at stake to be constitutionally protected for these purposes. It is also assumed that the third element, "public use," would also be satisfied under the broad view taken by the Supreme Court in Kelo v. City of the New London. ${ }^{146}$

141. See generally Copyright OfFICE Report, supra note 5; June M. BESEK, COPYRIGHT AND Related Issues Relevant to Digital Preservation and DisSemination of UnPublished Pre1972 SOUND RECORDINGS BY LIBRARIES AND ARCHIVES (2009), available at http://www. clir.org/pubs/reports/pub144/pub144.pdf (surveying state laws and exploring difficulties arising from non-uniform state law copyright protection); JUNE M. BESEK, COPYRIGHT Issues RELEVANT tO Digital Preservation and Dissemination of Pre-1972 Commercial Sound Recordings by LIBRARIES AND ARCHIVES (2005), available at http://www.clir.org/pubs/reports/pub135/pub135.pdf (same).

142. First English Evangelical Lutheran Church of Glendale v. L.A. County, 482 U.S. 304, 314 (1987); see also Brown v. Legal Found. of Wash., 538 U.S. 216, 231-32 (2003) ("[T]he text of the Fifth Amendment imposes two conditions on the exercise of such authority: the taking must be for a 'public use' and 'just compensation' must be paid to the owner.").

143. Lingle v. Chevron U.S.A. Inc., 544 U.S. 528, 537 (2005).

144. Id. (quoting Armstrong v. United States, 364 U.S. 40, 49 (1960)).

145. Ruckelshaus v. Monsanto Co., 467 U.S. 986, 1000-01 (1984) (applying this inquiry to a takings claim involving trade secrets).

146. Kelo v. City of New London, 545 U.S. 469, 475, 479-80, 484-85 (2005). In that case, as part of an economic revitalization plan, the city of New London authorized a private nonprofit entity to acquire parcels of land from private owners by purchase or by exercising eminent domain in the name of the City. Id. at 475 . In considering whether this forced transfer of property between private parties would satisfy a "public use," the Court reiterated that there was no strict requirement that "condemned property be put into use for the general public." Id. at 479. Rather, "public purpose" is the touchstone of the inquiry. Id. at 480. In light of the "comprehensive character of the plan" and "the thorough deliberation that preceded its adoption," the Court evaluated the claims of the individual owners "not on a piecemeal basis, but rather in light of the entire plan," which, it determined, served a public purpose. $I d$. at 484 . In the case of sound recordings, there would likely not be, for the reasons explained above, a naked transfer of ownership of the pre-1972 state law copyrights to other private parties equivalent to that seen in Kelo. The principal effect of federalization would be to eliminate the exclusive rights of current right holders ahead of schedule, with the goal of enhancing preservation and public access. Thus, federalizing legislation should satisfy the public use element of the takings analysis under Kelo. 
Accordingly, the remainder of this Article will focus on the second question (whether a taking has occurred) and, to a lesser extent, the fourth question (whether just compensation has been provided).

\section{B. Foreshortened Term of Protection}

The most significant impact federalization is likely to have is on the term of protection. As detailed above in Part III.B., the term of protection could be cut short for almost all published pre-1972 recordings, as well as for all unpublished recordings created prior to 1947 . With the proposed ninety-five-year term for published sound recordings (or 120 years for unpublished recordings), a sound recording published before 1923 could potentially lose anywhere from twentyseven years (if the extended term requirements are met) to forty-nine years of state law protection, assuming the effective date of federalizing legislation were January $1,2015 .{ }^{147}$ For those pre-1923 recordings, federalizing legislation would result in a loss of years of exclusivity - no matter what steps right holders undertook. Many other pre-1972 sound recordings would also lose years of protection unless right holders met the extended term requirements. This potential foreshortening of ownership for some categories of recordings, and the need to comply with the extended term requirements in others, could most predictably give rise to a cognizable claim.

\section{Due Process}

The Due Process analysis is relatively straightforward and should not pose a significant problem for federalizing legislation. Critically, the federalizing legislation would reflect a legitimate purpose: to enhance the preservation of and access to early sound recordings. It is in large measure the lack of parity in the treatment of early sound recordings and works created contemporaneously in other media that supports a legislative amendment. ${ }^{148}$ Specifically, works in other media copyrighted before 1978, and still under copyright, are entitled to a maximum of ninety-five years of copyright protection, ${ }^{149}$ and are subject to unfettered

The fact that certain members of the public, such as librarians and archivists, might particularly wish to access these works should not defeat this analysis. "Quite simply, the government's pursuit of a public purpose will often benefit individual private parties." $I d$. at 485 .

147. See supra note 49 and accompanying text.

148. See, for example, United States v. Sperry Corp., 493 U.S. 52, $64-65$ (1989), in which the Court rejected a due process challenge to legislation that imposed a $1.5 \%$ deduction, in favor of the U.S. Treasury, from awards secured in the Iran-United States Claims Tribunal. The appellee had obtained its award three months prior to the enactment of the statute, which had the effect of imposing a $\$ 42,000$ fee on the appellee. Id. Nevertheless, the Court upheld the legislation because the retrospective legislation aimed at ensuring consistency whereby the "costs of a program [were] borne by the entire class of persons that Congress rationally believe[d] should bear them." Id. at 65 . Thus, successful Tribunal claimants, who had all benefited from its mechanisms, could justifiably be compelled to pay fees, regardless of whether they happened to secure their awards prior to or subsequent to the legislation. Id. at $64-65$.

149. 17 U.S.C. $\S 304$ (2012). 
preservation efforts and public access at the conclusion of that term. By contrast, almost no sound recordings are currently in the public domain throughout the country, nor are they likely to be so until $2067 .{ }^{150}$

The comparison is particularly stark with respect to works published prior to 1923. For example, a musical composition published in 1922 would have become part of the public domain at the end of $1997 ; ;^{151}$ by contrast, a sound recording of the same vintage, which may be physically deteriorating and irreplaceable, ${ }^{152}$ will not enter the public domain until 2067-that is, seventy years later. Through the federalizing legislation, Congress could put right holders of all categories of pre1978 works, including those of all pre-1978 sound recordings, ${ }^{153}$ on a more even footing with respect to the term of protection. The arbitrary distinction between the legal treatment of pre- and post-February 15, 1972 sound recordings would largely disappear. ${ }^{154}$

While the legislative fix comes many years after the initial legislation, ${ }^{155}$ it nonetheless is rationally related to the specified purpose. The call for renewed Congressional attention to early sound recordings arose, in part, from a series of reports sponsored or commissioned by the National Recording Preservation Board between 2005 and 2010. ${ }^{156}$ The delay in ameliorative legislation would simply reflect a delay in the emergence of evidence that there was a problem.

The rational relationship between the federalizing legislation and its purposes is further demonstrated by the narrow tailoring of its harshest elements: the sole category of pre-1972 sound recordings that would never be eligible for an extended term until 2067 are those that were published before 1923; as described above, these extremely old recordings would only be eligible for an additional twenty-five years of protection. However, all works in other media published before 1923 are already in the public domain. Thus, the fact that the federalizing legislation confines its most demanding aspects to these earliest sound recordings-indeed, those which may be in most need of preservation - reflects rational tailoring. ${ }^{157}$

150. See supra note 20 and accompanying text.

151. See COPYRIGHT OFFICE REPORT, supra note 5, at 5.

152. Id. at 56-58 (outlining some of the challenges and risks).

153. As mentioned, different treatment is accorded to certain foreign sound recordings. See supra notes 32-37 and accompanying text. Furthermore, right holders of sound recordings published before 1923 would still enjoy a privileged position through compliance with the extended term requirements, since they could still obtain an additional twenty-five years of protection, whereas works in other media published before 1923 are in the public domain.

154. Accord United States v. Carlton, 512 U.S. 26, 35 (1994) (upholding a "curative" amendment to the federal tax code that retroactively closed a tax loophole fourteen months after the enactment of the original law, thereby depriving an estate of a deduction that would have reduced estate taxes by $\$ 2.5$ million).

155. It is true that the legislative fix implemented by federalizing legislation would be much further removed in time from the original legislation than in Sperry or Carlton. See Fisch, supra note 97, at 1074 ("In its opinion in Carlton, the Court suggested criteria for evaluating the rationality of retroactive legislation, including the remedial nature of the statute and the period of retroactive operation."). But the nature of the problem to be fixed was more immediately recognized in those settings than in the present context.

156. See COPYRIGHT OFFICE REPORT, supra note 5, at 3 (citing sources).

157. The Copyright Office recommended a maximum of twenty-five years of federal protection for 
For these reasons, although the federalizing legislation might deprive certain right holders of the value of their state law copyrights for a portion of the current state law term, we think that federalizing legislation would not violate due process. While these right holders may have relied on the state law regime, even "[a]n entirely prospective change in the law may disturb the relied-upon expectations of individuals, but such a change would not be deemed to be therefore violative of due process. $" 158$

\section{Takings}

With respect to whether a taking has occurred, the Supreme Court has developed two categories of takings jurisprudence. A taking in the classic sense is a "direct government appropriation or physical invasion of private property," 159 which imposes upon the government the "categorical duty to compensate the former owner." 160 The foreshortening of a copyright term is better analyzed under the Court's regulatory takings jurisprudence. ${ }^{161}$ The goals in applying this framework are to measure the "severity of the burden that government imposes upon private property rights," and to assess whether the governmental action is "functionally equivalent to the classic taking in which government directly appropriates private property or ousts the owner from his domain." 162 The principal challenge undertaken in this Article is to convert the jurisprudence, which focuses on land rights and usage, to the present copyright-oriented context. ${ }^{163}$

pre-1923 recordings in part because recordings from that era "are usually of such low quality that relatively few of them are marketable." COPYRIGHT OFFICE REPORT, supra note 5, at 164.

158. Carlton, 512 U.S. at 33-34.

159. Lingle v. Chevron U.S.A. Inc., 544 U.S. 528, 537 (2005). Such a transfer of property can be either to the government or to a private party. See Stop the Beach Renourishment, Inc. v. Fla. Dep't of Envtl. Prot., 130 S. Ct. 2592, 2596 (2010) (plurality opinion) ("[C]lassic taking is a transfer of property to the State or to another private party by eminent domain ...."); see also Kelo v. City of New London, 545 U.S. 469, 475 (2005) (assessing takings in the context of an economic revitalization plan under which private property would be transferred by eminent domain from one set of private parties to another).

160. Tahoe-Sierra Pres. Council, Inc. v. Tahoe Reg'l Planning Agency, 535 U.S. 302, 322 (2002). In addition, "while property may be regulated to a certain extent, if regulation goes too far it will [also] be recognized as a taking." Penn. Coal Co. v. Mahon, 260 U.S. 393, 415 (1922). In determining how far is "too far," courts must "remain cognizant that 'government regulation by definition involves the adjustment of rights for the public good." Lingle, 544 U.S. at 538 (2005) (quoting Andrus v. Allard, 444 U.S. 51, 65 (1979)).

161. The frameworks used in the land-use exaction cases do not seem relevant here, as those cases involved land use permits and, in any event, no analogous conduct is implicated by the mere promulgation of federalizing legislation. See Koontz v. St. John's River Water Mgmt. Dist., 133 S. Ct. 2586 (2013); Dolan v. City of Tigard, 512 U.S. 374 (1994); Nollan v. Cal. Coastal Comm'n, 483 U.S. 825 (1987).

162. Lingle, 544 U.S. at 539.

163. An important subsidiary question is whether a regulatory takings claim would be framed as a facial or as applied challenge. Claimants seeking to mount a facial challenge "face an uphill battle." Tahoe-Sierra Pres. Council, 535 U.S. at 320 (quoting Keystone Bituminous Coal Ass'n v. DeBenedictis, 480 U.S. 470, 495 (1987)). As the Court has formulated it, the test for a facial challenge is whether a statute, by its mere enactment, denies an owner of the economically viable use of his 


\section{a. Per Se Taking}

A regulation through which the government requires a property owner to endure a permanent physical invasion of his property will effect a per se taking. ${ }^{164}$ A per se rule will also apply to a "total regulatory taking" that completely deprives a property owner of "all economically beneficial use[]" of the property. ${ }^{165}$ The latter two are "categories of regulatory action [that are] . . . compensable without casespecific inquiry into the public interest advanced in support of the restraint." 166

In contrast to these "acquisitions of property for public use" are "regulations prohibiting private uses."167 Such prohibitions require "complex factual assessments of the purposes and economic effects of government actions." $" 168$ This more common type of government regulation is evaluated by the standards outlined in the Penn Central balancing test. ${ }^{169}$ One significant difference between the categorical, per se approach and the ad hoc Penn Central approach is the degree of individualized factual development required to bring a successful claim. Unlike the Penn Central framework, the per se framework would allow the court "to apply a clear rule." 170 The Supreme Court has explained that one reason for distinguishing between classic, categorical takings and Penn Central-type regulatory takings is that if courts were to treat all land-use regulations-which are ubiquitous and inevitably affect property values - as per se takings, that approach would "transform government regulation into a luxury few governments could afford." "171 "By contrast, physical appropriations are relatively rare, easily identified, and usually represent a greater affront to individual property rights." ${ }^{172}$

At first blush, there would seem to be a mismatch between a physically invasive regulatory taking and the act of extending federal copyright protection to intangible interests like state law copyrights. ${ }^{173}$ Such per se takings are typically tied to a

property. $I d$. If a facial challenge fails, plaintiffs typically are able to bring an as applied challenge. See Guggenheim v. City of Goleta, 638 F.3d 1111, 1119 (9th Cir. 2010) (en banc).

164. See Lingle, 544 U.S. at 538 (citing Loretto v. Teleprompter Manhattan CATV Corp., 458 U.S. $419(1982))$.

165. See Lucas v. S.C. Coastal Council, 505 U.S. 1003, 1019, 1026-30 (1992); accord United States v. Sec. Indus. Bank, 459 U.S. 70, 82 (1982) ("Since the governmental action here would result in a complete destruction of the property right of the secured party, the case fits but awkwardly into the analytic framework employed in Penn Central Transportation Co.....").

166. Lucas, 505 U.S. at 1015.

167. Tahoe-Sierra Pres. Council, 535 U.S. at 323.

168. Id.

169. Lingle, 544 U.S. at 538 (citing Penn Cent. Transp. Co. v. City of New York, 438 U.S. 104 (1978)).

170. Brown v. Legal Found. of Wash., 538 U.S. 216, 234 (2003) (quoting Yee v. Escondido, 503 U.S. 519, 523 (1992) (internal quotation marks omitted)).

171. Tahoe-Sierra Pres. Council, 535 U.S. at 324.

172. Id

173. We think that the other category of per se regulatory taking, under Lucas, ought not to apply here in light of Tahoe-Sierra, 535 U.S. at 331, which emphasizes the treatment of a parcel of property as a whole, rather than deprivations that were effectuated during any particular temporal segment, in determining which takings framework is applicable. Under the federalizing legislation as conceived, there would not be a "total taking" of the entire state-protected copyright interest. Id. at 331; accord 
government intrusion upon a real property interest. Nevertheless, there is precedent that would support such an approach. In Brown v. Legal Foundation of Washington, the Supreme Court considered the appropriate framework through which to assess the compulsory transfer of interest accruing in so-called interest on lawyers' trust accounts (IOLTAs). ${ }^{174}$ In an earlier case, the Court determined that the interest income earned by funds held in the IOLTA accounts was the "private property of the owner of the principal."175 In Brown, the Court reasoned that something akin to a "permanent physical invasion" (and hence, taking) had occurred. ${ }^{176}$ Without explaining in any detail why the analogy was appropriate, the Court simply stated its conclusion that the transfer of IOLTA account interest from its owner to a public interest foundation, as required by state law, was a per se taking. ${ }^{177}$

As discussed above, federalizing legislation should be drafted to ensure that, at the outset of the federal term, ownership of the federal copyright in pre-1972 sound recordings is determined according to the prior existing state law. ${ }^{178}$ Nevertheless, there would still remain the "naked" transfer of rights in the recording from the right holders to the public with respect to the truncated portion of the state law term. Can it be said that federalizing legislation with this characteristic categorically "takes" that portion of the term? The Court has contrasted per se takings with Penn Central-type regulatory takings, saying that the latter do "not give the government any right to use the property, nor [do they] dispossess the owner or affect her right to exclude others." 179 Arguably, by eliminating in some cases portions of the terms of the state law copyrights - which entitle the right holder to exclude others for many purposes - the federalizing legislation would tread close to this line of demarcation.

Professor Thomas Cotter has addressed the question of which takings framework should be used to assess government uses of intellectual property. ${ }^{180}$ In particular, he draws upon two lines of precedent that may be compared to the

Nestor M. Davidson, The Problem of Equality in Takings, 102 Nw. U. L. REV. 1, 31 (2008) (“[A]nything short of a total deprivation must be decided under Penn Central ....."). Furthermore, the Lucas Court itself suggested that its analysis was more applicable to real, rather than personal, property interests. Lucas v. S.C. Coastal Council, 505 U.S. 1003, 1027-28 (1992).

174. 538 U.S. 216 (2003); see also Koontz v. St. John's River Water Mgmt. Dist., 133 S. Ct. 2586, 2600 (2013) (suggesting that "when the government commands the relinquishment of funds linked to a specific, identifiable property interest such as a bank account or parcel of real property, a "per se [takings] approach' is the proper mode of analysis").

175. Phillips v. Washington Legal Foundation, 524 U.S. 156, 172 (1998).

176. Brown, 538 U.S. at 235 (citing Loretto v. Teleprompter Manhattan CATV Corp., 458 U.S. 419 (1982)). At issue in Loretto was a New York statute that required landlords to permit the installation of cable facilities on their rooftops and exteriors. Loretto, 458 U.S. at 421 . The Court held that permanent physical occupation of even a small portion of an owner's parcel constituted a per se taking. Id. at 426, 436-38.

177. Brown, 538 U.S. at 235. The Court concluded, however, that no compensation was due because no pecuniary loss had been incurred by the property owners. Id at 240 .

178. See discussion supra Part III.B.4.

179. Tahoe-Sierra Pres. Council, Inc. v. Tahoe Reg'l Planning Agency, 535 U.S. 302, 324 n.19 (2002).

180. See Cotter, supra note 129. 
present inquiry into sound recordings. First are cases in the patents area, where courts have struggled with the question of whether the government's use of a patented invention without a license can constitute a compensable taking. ${ }^{181}$ The second is the Supreme Court's decision in Ruckelshaus v. Monsanto Co., which involved a challenge to a federal law allowing the Environmental Protection Agency (EPA) to use and publicly disclose trade secret-protected data that applicants for the registration of pesticides had submitted. ${ }^{182}$

Noting the seeming contrast between the tradition of categorical compensation for patent owners and the Court's application of an ad hoc approach in Ruckelshaus, Cotter argues that perhaps the categorical approach is preferable because uses by the government interfere with the "fundamental" property right of exclusion. ${ }^{183}$ Importantly, he suggests that "in some respects this right to exclude may be more fundamental in the context of intellectual property than it is in the context of real property." 184 His justification is that intellectual property rights typically confer on the right holder only negative rights to exclude others from engaging in certain acts, rather than affirmative rights to take those steps oneself. Thus, deprivation of the right to exclude eviscerates precisely what makes the property worth owning. ${ }^{185}$

The present context should be distinguished, however. First, as part of his analysis, Cotter attaches weight to the kind of "singling out" that occurs in the government uses he has identified. ${ }^{186}$ Thus, in the patent cases, the government was actively practicing the patented inventions without payment-in some cases, like defense weapons systems, where the government itself was likely to have been the only possible paying licensee for the patented invention. ${ }^{187}$ And, under the legislative regime scrutinized in Ruckelshaus, the authorized uses included the EPA's use of the data to evaluate the applications of later pesticide registrants as long as the second comer offered to compensate the original submitter. ${ }^{188}$

By contrast, the government is not seeking, through the federalizing legislation, to "use" or gain access to pre-1972 sound recordings. ${ }^{189}$ That is, the government

181. In protracted patent litigation, the Federal Circuit has wrestled with whether alleged patent infringement by the government could constitute a Fifth Amendment taking. See Zoltek Corp. v. United States, 442 F.3d 1345, 1352-53 (Fed. Cir. 2006) (rejecting argument that alleged patent infringement by government could be addressed as Fifth Amendment taking under Tucker Act), vacated by Zoltek Corp. v. United States, 672 F.3d 1309, 1327 (Fed. Cir. 2012).

182. Ruckelshaus v. Monsanto Co., 467 U.S. 986, 990 (1984).

183. Kaiser Aetna v. United States, 444 U.S. 164, 179-80 (1979).

184. See Cotter, supra note 129 , at 560.

185. See Ruckelshaus, 467 U.S. at 1011-12; Adam Mossoff, Patents as Constitutional Private Property: The Historical Protection of Patents Under the Takings Clause, 87 B.U. L. REv. 689, 720 (2007) (describing the evolution from the nineteenth century conception of patent rights as use-rights to the contemporary twentieth century conception of them as exclusion rights).

186. See Cotter, supra note 129 , at 562.

187. See id. at 539-42.

188. Ruckelshaus, 467 U.S. at 994

189. That is, the federalizing legislation does not appear to be "conscript[ing]" property through seemingly "proscriptive" rules. See Jed Rubenfeld, Usings, 102 YALE L.J. 1077, 1080 (1993) (arguing that such activity lies at the heart of the takings analysis). 
would not be "singling out" certain right holders so that the government (through federally operated libraries and archives) or the public could freely reproduce or distribute the recordings. Rather, the contemplated legislation would be a legislative fix to ensure that a large category of works, pre-1972 sound recordings, is brought within the fold of a unified federal copyright system. The legislation would aim to ensure that pre-1972 sound recordings do not retain preferable treatment to other works in a way that puts their very preservation and survival at risk. It is for precisely these sorts of reasons that Professor Davida Isaacs forcefully argued against the extension of takings protections to patents: concern that a proliferation of regulatory takings claims would lead the government to "hesitate to make socially valuable reforms [to patent law], thus injuring the public." 190

Under Professor Cotter's analysis, it is true that if the government's use of a single patent is a categorical taking because it interferes with the exclusive rights of the patentee, then a fortiori, a generally applicable law that interferes with the exclusive rights of all sound recordings published before 1923 should be all the more subject to a categorical analysis. But this ignores the fact that the federalizing legislation would not simply be taking away the final years of protection for the earliest pre-1972 sound recordings so as to make the term of protection more comparable to that enjoyed by works in other media of the same era. Critically, during the minimum guaranteed federal term that would be granted to right holders in return, the federalizing legislation would also be guaranteeing certain valuable exclusive rights that may not exist under the laws of the several states, including a more certain derivative work right and public performance right in the case of digital audio transmissions. In this sense, there is arguably implicit compensation to right holders within the federalizing legislation itself. ${ }^{191}$

Accordingly, it is not accurate to describe the federalizing legislation solely as an "acquisition . . . of property for public use" 192 requiring the per se treatment applied in Brown, where all IOLTA account interest was transferred away from every owner without any compensating benefits. Here, some right holders may actually prefer the slate of federal rights to a longer, but less clear, term of state law protection. Furthermore, even in Ruckelshaus, where the EPA was actively using the proprietary information at issue, the Court applied the Penn Central framework to legislation affecting trade secrets. ${ }^{193}$ Finally, given Congress' unremarked upon pattern of bringing federal unity to copyrightable subject matter, ${ }^{194}$ and in particular

190. See Isaacs, supra note 124 , at 3 .

191. See, e.g., Richard A. EPSTEIN, TAKINGS: PRIVATE Property AND THE POWER OF EMINENT DomaIN 195-215 (1985); Thomas W. Merrill, Incomplete Compensation for Takings, 11 N.Y.U. ENVTL. L.J. 110, 121-22 (2002); see also Carol M. Rose, Mahon Reconstructed: Why the Takings Issue Is Still a Muddle, 57 S. CAL. L. ReV. 561, 581-82 (1984).

192. Tahoe-Sierra Pres. Council, Inc. v. Tahoe Reg'l Planning Agency, 535 U.S. 302, 323 (2002).

193. Ruckelshaus, 467 U.S. at 1005-06. Professor Cotter points out, however, that the Court does use a kind of "per se" approach with respect to data the right holder submitted during one particular window of time because of the legislation's effect on the right holder's "reasonable investment-backed expectations" in submitting that data. See Cotter supra note 129, at 561.

194. In another context in which congressional power to regulate the term of copyright protection 
its prior withdrawal of perpetual protection for pre-1972 sound recordings and unpublished works in all media, the Penn Central balancing test-which would obligate a complaining stakeholder to prove certain kinds of economic reliance and harm-is more appropriate. ${ }^{195}$

Even if a court were to apply a per se takings analysis, however, the lengthy period of state law protection already enjoyed by pre-1972 sound recordings is akin to an amortization period for nonconforming uses under zoning law, which some courts have found to vitiate takings claims. ${ }^{196}$

\section{b. Penn Central Taking}

A reviewing court should instead apply the Penn Central regulatory takings factors. Primary among these factors are " $[t]$ he economic impact of the regulation on the claimant and, particularly, the extent to which the regulation has interfered with distinct investment-backed expectations." 197 Also relevant is the "character of the governmental action," such as whether the interference amounts to a "physical invasion by government" rather than to "some public program adjusting the benefits and burdens of economic life to promote the common good"198 in a "manner that secures an 'average reciprocity of advantage' to everyone concerned." 199

\section{i. "Economic Impact"}

Even if revocation of some period of state law protection were to reduce the value of copyright holders' interests in their pre-1972 recordings, the Supreme Court in Penn Central rejected the notion that "diminution in property value, standing alone, can establish a 'taking." "200 In that case, the Court considered the

was challenged, the Court explicitly relied upon historical practice: "To comprehend the scope of Congress' power under the Copyright Clause, 'a page of history is worth a volume of logic."' Eldred v. Ashcroft, 537 U.S. 186, 200 (2003) (quoting New York Trust Co. v. Eisner, 256 U.S. 345, 349 (1921) (Holmes, J.)). The fact that Eldred dealt with expanded terms, rather than foreshortened terms, does not refute the importance of the history of congressional activity in this area.

195. Accord Ark. Game \& Fish Comm'n v. United States, 133 S. Ct. 511, 518 (2012) (citing Penn Cent. Transp. Co. v. City of New York, 438 U.S. 104, 124 (1978)) (emphasizing that "most takings claims turn on situation-specific factual inquiries" rather than on the application of bright line rules).

196. See Christopher Serkin, Existing Uses and the Limits of Land Use Regulations, 84 N.Y.U. L. REV. 1222, 1244-45 (2009); Deepa Varadarajan, Note, Billboards and Big Utilities: Borrowing LandUse Concepts to Regulate "Nonconforming" Sources Under the Clean Air Act, 112 YALE L.J. 2553, 2573-76 (2003).

197. Penn Central, 438 U.S. at 124.

198. Id.

199. Lucas v. S.C. Coastal Council, 505 U.S. 1003, 1018 (1992) (quoting Penn. Coal Co. v. Mahon, 260 U.S. 393, 415 (1922)). More recently, the Court has emphasized that "the magnitude or character of the burden a particular regulation imposes upon private property rights" and "how any regulatory burden is distributed among property owners" factor into the Penn Central inquiry. Lingle v. Chevron U.S.A. Inc., 544 U.S. 528, 542 (2005).

200. Penn Central, 438 U.S. at 131; accord Concrete Pipe \& Prods. of Cal., Inc. v. Constr. Laborers Pension Trust for S. Cal., 508 U.S. 602, 645 (1993) ("[O]ur cases have long established that 
application of New York City's Landmarks Preservation Law to Grand Central Terminal, pursuant to which the building's owners (Penn Central) had been denied the right to construct an office tower atop the Terminal. ${ }^{201}$ In evaluating the impact of the landmarks law on the owners' parcel, the Court found it significant that the landmark designation did not interfere with the primary uses to which the Terminal had been put for the prior sixty-five years, namely, a railroad terminal with office space and concessions. ${ }^{202}$ It remarked that, from the record before it, the law permitted "Penn Central not only to profit from the Terminal but also to obtain a 'reasonable return' on its investment.",203

Furthermore, the Court found other aspects of the regulatory regime mitigated the impact of the law's restriction on Penn Central's air rights. It noted that even if Penn Central could not build the contemplated tower on the desired property, Penn Central's pre-existing air rights had not been abrogated since they were transferable to other parcels that Penn Central owned in the vicinity of the Terminal, some of which were well suited for new office building construction. ${ }^{204}$ While the transferable development-rights program might not have been "ideal,"

[t]he rights afforded [to Penn Central in this case] are valuable. While these rights may well not have constituted "just compensation" if a "taking" had occurred, the rights nevertheless undoubtedly mitigate whatever financial burdens the law has imposed on appellants and, for that reason, are to be taken into account in considering the impact of regulation. ${ }^{205}$

Later cases underscore that any statutory provisions that "moderate and mitigate the economic impact" are relevant to this analysis. ${ }^{206}$

Building on Penn Central, the Court has emphasized the treatment of a parcel of property as a whole, rather than deprivations that were effectuated during any particular temporal segment. ${ }^{207}$ In Tahoe-Sierra Preservation Council, Inc. v. Tahoe Regional Planning Agency, the Court held that a thirty-two-month moratorium on virtually all development - that is, "all economically viable use"by property owners of their property was not a categorical taking but should be judged through the ad hoc, context-specific Penn Central framework, ${ }^{208}$ which "requires careful examination and weighing of all the relevant circumstances." 209

\footnotetext{
mere diminution in the value of property, however serious, is insufficient to demonstrate a taking.").

201. Penn Central, 438 U.S. at 115-17.

202. Id. at 136 .

203. Id.

204. Id. at 137 .

205. Id.

206. Connolly v. Pension Benefit Guar. Corp., 475 U.S. 211, 225-26 (1986).

207. Tahoe-Sierra Pres. Council, Inc. v. Tahoe Reg'l Planning Agency, 535 U.S. 302, 331 (2002) (collecting cases); see also Penn Central, 438 U.S. at 130 (“"Taking' jurisprudence does not divide a single parcel into discrete segments and attempt to determine whether rights in a particular segment have been entirely abrogated.").

208. Tahoe-Sierra Pres. Council, 535 U.S. at 320-21. Although for ease of language we refer to one "moratorium," in fact there were two moratoria, which together lasted thirty-two months. $I d$. at 306. 209. Id. at 335 (quoting Palazzolo v. Rhode Island, 533 U.S. 606, 636 (2001) (O’Connor, J., concurring)).
} 
Specifically, the Court stated that

the District Court erred when it disaggregated petitioners' property into temporal segments corresponding to the regulations at issue and then analyzed whether petitioners were deprived of all economically viable use during each period. ${ }^{210}$

The Tahoe-Sierra Preservation Council Court was not, however, unanimous in this view, ${ }^{211}$ and that case is distinguishable from the present inquiry in significant ways. In Tahoe-Sierra Preservation Council, the Court noted that the temporary deprivation of use would be alleviated when the restriction - a moratorium intended to arrive at a comprehensive plan for use of the land-ended. ${ }^{212}$ Furthermore, the reason for the moratorium was to "maintain the status quo while studying the impact of development on Lake Tahoe and designing a strategy for environmentally sound growth." 213 Thus, one could expect that despite, or even because of, the moratorium on development, property values would actually rise, to the ultimate benefit of the affected property owners, "reflect[ing] the added assurance that Lake Tahoe will remain in its pristine state." 214 The Court conceded that "[i]t may well be true that any moratorium that lasts for more than one year should be viewed with special skepticism," but it said that the thirty-two months required was "not unreasonable" and that "we could not possibly conclude that every delay of over one year is constitutionally unacceptable." 215

By contrast, in the case of pre-1972 sound recordings, any suspension in a state copyright holder's exclusive use would arise in connection with an irreversible termination of state law rights. It is also difficult to argue that the foreshortening of the state law term of its own accord would ultimately inure to the benefit of those right holders. (Although, as previously underscored, the federalizing legislation would secure for right holders a set of exclusive federal rights in return.) Furthermore, as described above, the elimination of the number of years of protection could far exceed the two to three years of use at issue in Tahoe-Sierra Preservation Council.

Although the Court's cautioning against the employment of temporal segments in Tahoe-Sierra Preservation Council addressed the discrete question of which takings framework is applicable, its analysis is also relevant to the measurement of the economic impact of the federalizing legislation on right holders. The economic impact of the legislation should be measured against the value of the entire life of the rights in the pre-1972 sound recording.

210. Id. at 331 (citation omitted).

211. In his dissent, Justice Thomas, joined by Justice Scalia, argued against the notion that a regulatory taking must be judged in relation to the "parcel as a whole." Id. at 355 (Thomas, J., dissenting). He argued that "a regulation effecting a total deprivation of the use of a so-called "temporal slice' of property is compensable under the Takings Clause unless background principles of state property law prevent it from being deemed a taking ...."Id. (Thomas, J., dissenting). Nevertheless, this was not the position of the majority.

212. Tahoe-Sierra Pres. Council, 535 U.S. at 332.

213. Id. at 306 .

214. Id . at 341 .

215. Id. at 341-42. 
Perhaps the strongest case law that would counsel against the finding of a taking in the context of federalization of pre-1972 sound recordings is Andrus v. Allard. ${ }^{216}$ Decided just one year after Penn Central, the Court in Andrus noted the fact that the regulations at issue, which prevented the sale of parts of birds legally killed before the birds became subject to statutory protection, did not require the parts be surrendered, nor did it entail physical invasion or restraint of them. ${ }^{217}$ Thus, although one means of disposing them had been significantly impaired (i.e., by sale), the "denial of one traditional property right does not always amount to a taking. At least where an owner possesses a full 'bundle' of property rights, the destruction of one 'strand' of the bundle is not a taking, because the aggregate must be viewed in its entirety." 218 And in this case, it was "crucial that appellees retain[ed] the rights to possess and transport their property, and to donate or devise the protected birds." 219 Thus, it was not clear that "appellees [would] be unable to derive economic benefit from the artifacts; for example, they might exhibit the artifacts for an admissions charge. At any rate, loss of future profitsunaccompanied by any physical property restriction-provides a slender reed upon which to rest a takings claim." 220

If the current Court were to apply this reasoning, it would seem at the very least to require direct evidence of economic impact from current copyright holders rather than vague claims about lost value pertaining to the portion of the state copyright term that is forfeited under federalization. ${ }^{221}$

\section{ii. "Distinct investment-backed expectations"}

Investment decisions and contractual arrangements have likely been built around a state law based framework for protection. Such protection for pre-1972 sound recordings has long been in place and the 1976 Act arguably buttressed the expectation of uninterrupted state law protection of those recordings until the middle of the twenty-first century. ${ }^{222}$ Thus, one argument is that not only have investment-backed expectations been in place for decades, but such expectations were also reaffirmed by the significant overhaul of the copyright system that occurred in 1976.

\footnotetext{
216. 444 U.S. 51 (1979).

217. Id. at 65 .

218. Id. at $65-66$

219. Id. at 66

220. Id.

221. By way of comparison to concrete figures, in Hodel v. Irving, the Court suggested that while loss of $\$ 100$ might be inconsequential, the value of the other interests at issue in the case, which would escheat on account of the legislation, were \$2,700 and \$1,816 - “" not trivial sums." Hodel v. Irving, 481 U.S. 704, 714 (1987). In Eastern Enterprises, the Court found the payments required of the petitioner under the Coal Act of $\$ 50$ million to $\$ 100$ million to be a "considerable financial burden." Eastern Enters. v. Apfel, 524 U.S. 498, 529 (1998) (plurality opinion).

222. Federal preemption of state laws protecting sound recordings was initially set to occur on February 15, 2047; with the Sonny Bono Copyright Term Extension Act, Pub. L. No. 105-298, 112 Stat. 2827 (1998), the date was extended by twenty years, until February 15, 2067.
} 
Nevertheless, as explained above, copyright law more generally has been the subject of legislative revision. ${ }^{223}$ The 1976 Act changed the framework for protection, across media, of unpublished works. ${ }^{224}$ With respect to pre-1972 sound recordings in particular, the 1976 Act revoked what had been perpetual state law protection for these recordings. Thus, expectations of such changes from time to time arguably are now built into the fabric of these property rights. ${ }^{225}$ By itself, however, the pattern of frequent amendment of the copyright statute would not automatically weigh against a takings claim. That is, the mere fact that holders of copyright interests in pre-1972 sound recordings might be deemed to have notice of the frequent changes in federal copyright law would not necessarily prevent a takings claim. In Palazzolo v. Rhode Island, for example, the Supreme Court held that the fact that the property owner had acquired the land at issue with notice of regulations restricting use did not foreclose a takings claim. ${ }^{226}$ Thus, even those copyright holders who had acquired their interests in recent years, with additional knowledge of the frequency with which the law has been amended, might not be defeated by this factor. Nevertheless, the reasonableness of expectations in the context of the regulatory scheme is a factor to be considered. ${ }^{227}$ The Court has made clear that those "who do business in the regulated field cannot object if the legislative scheme is buttressed by subsequent amendments to achieve the legislative end."228

Furthermore, the presence or absence of an "average reciprocity of advantage" from the legislative change is also relevant. In Hodel v. Irving, for example, the statute at issue required that certain undivided fractional interests in land owned by Native Americans would escheat, upon the death of the owner, to his or her tribe. ${ }^{229}$ Three members of the Oglala Sioux Tribe brought suit challenging the statute. The Supreme Court noted that many members of the Tribe whose fractional interests

223. See, e.g., Eldred v. Ashcroft, 537 U.S. 186, 194-96 (2003).

224. Of course, with respect to works that a creator never plans to publish, it is unlikely that investment-backed expectations are significant.

225. See Isaacs, supra note 124, at 28 (noting that "it is unclear how the courts would apply the concept of 'background principles' to patents").

226. See Palazzolo v. Rhode Island, 533 U.S. 606, 628 (2001) (noting that "[a] blanket rule that purchasers with notice have no compensation right when a claim becomes ripe is too blunt an instrument to accord with the duty to compensate for what is taken," and remanding for application of Penn Central factors); see also Philip Morris, Inc. v. Reilly, 312 F.3d 24, 34 n.5, 37 (1st Cir. 2002) (en banc) (describing the Palazzolo holding as "whether property is acquired before or after a regulation is enacted does not completely determine the owner's reasonable investment-backed expectations"); Abbott Labs. v. CVS Pharmacy, Inc., 290 F.3d 854, 860 (7th Cir. 2002).

227. Palazzolo, 533 U.S. at 633 (O’Connor, J., concurring) ("[I]nterference with investmentbacked expectations is one of a number of factors that a court must examine. Further, the regulatory regime in place at the time the claimant acquires the property at issue helps to shape the reasonableness of those expectations.'); Penn Cent. Transp. Co. v. City of New York, 438 U.S. 104, 124 (1978).

228. Concrete Pipe \& Prods. of Cal., Inc. v. Constr. Laborers Pension Trust for S. Cal., 508 U.S. 602, 645 (1993) (citation omitted). Moreover, the "fact that legislation disregards or destroys existing contractual rights does not always transform the regulation into an illegal taking"; rather, "[i]f the regulatory statute is otherwise within the powers of Congress . . . its application may not be defeated by private contractual provisions.” Connolly v. Pension Benefit Guar. Corp., 475 U.S. 211, 224 (1986).

229. Hodel v. Irving, 481 U.S. 704, 709 (1987). 
would escheat would actually benefit from the escheat of the interests of other members of the Tribe. ${ }^{230}$ Accordingly, it determined that this "average reciprocity of advantage" would weigh "weakly" in favor of the statute. Could an equivalent tradeoff exist for sound recording copyright owners to the extent that they get equivalent rights that make up for the loss of years of protection?

In Eastern Enterprises v. Apfel, a plurality of the Court determined that reasonable investment-backed expectations favored the party challenging the statute. ${ }^{231}$ In that case, petitioner Eastern Enterprises would have been liable under the Coal Act for lifetime medical benefits for employees who had worked for the company thirty to fifty years before the statute was enacted, a liability which was expected to total between $\$ 50$ million and $\$ 100$ million. ${ }^{232}$ This liability was imposed "without any regard to responsibilities that Eastern accepted under any benefit plan the company itself adopted." 233 The Court determined that the premiums for which Eastern would now be liable were "not calibrated either to Eastern's past actions or to any agreement-implicit or otherwise-by the company. Nor would the pattern of the Federal Government's involvement in the coal industry have given Eastern 'sufficient notice' that lifetime health benefits might be guaranteed to retirees several decades later." 234 Assessing the Penn Central factors, the Court found the statute to effect a "severe, disproportionate, and extremely retroactive burden on Eastern," which violated the Takings Clause as applied to Eastern. ${ }^{235}$

In Ruckelshaus v. Monsanto Co., the Court examined a takings claim with respect to trade secrets. ${ }^{236}$ During the time frame in which the Court found a potential taking, Monsanto had submitted its health, safety and environmental data to the EPA under a statutory assurance of confidentiality and exclusive use. ${ }^{237}$ The Court characterized the "right to exclude others" as "central to the very definition of the property interest" at stake when it comes to trade secrets, for once they are disclosed or others are allowed to use them, "the holder of the trade secret has lost his property interest in the data." 238

At the Pre-1972 Sound Recordings Public Meeting in June 2011, it was suggested that this concern might not carry the same weight with respect to sound recordings. ${ }^{239}$ This is so because those who hold the masters or otherwise have a lead-time advantage can still monetize their recordings even should they fall into the public domain. Nevertheless, it is not clear how much purchase such an

\footnotetext{
230. Id. at $715-16$.

231. Eastern Enters. v. Apfel, 524 U.S. 498, 529 (1998) (plurality opinion).

232. Id. at 531 .

233. Id.

234. Id. at 536 .

235. Id. at 538 .

236. Ruckelshaus v. Monsanto Co., 467 U.S. 986 (1984).

237. Id. at 1011 .

238. Id.

239. Eric Harbeson, Music Library Ass'n, Comments at Pre-1972 Sound Recordings Public Meeting 19 (June 2, 2011), available at http://www.copyright.gov/docs/sound/meeting/transcript-06-022011.pdf.
} 
argument should have, since a similar argument was rejected by the Supreme Court in Ruckelshaus:

That the data retain usefulness for Monsanto even after they are disclosed-for example, as bases from which to develop new products or refine old products, as marketing and advertising tools, or as information necessary to obtain registration in foreign countries - is irrelevant to the determination of the economic impact of the EPA action on Monsanto's property right. The economic value of that property right lies in the competitive advantage over others that Monsanto enjoys by virtue of its exclusive access to the data, and disclosure or use by others of the data would destroy that competitive edge. ${ }^{240}$

Critically, the Court rejected EPA's argument in favor of uniformity in the form of a "comprehensive FIFRA registration scheme" - even more important in view of its tie to public health and safety than copyright legislation-to displace the vagaries of state law. ${ }^{241}$

\section{iii. "Character of the Governmental Action"}

Under this prong of the Penn Central analysis, courts consider whether the government "physically invade[s] or permanently appropriate[s]" property, or whether it is creating "a public program that adjusts the benefits and burdens of economic life to promote the common good." 242 They also consider whether the government is "forcing some people alone to bear public burdens which, in all fairness and justice, should be borne by the public as a whole." 243 With respect to the latter consideration, is a shift from state to federal protection likely to entail a "singling out" of current state law interest holders? If so, the character of the governmental action might weigh in favor of a taking. ${ }^{244}$

If the character of the action is to abrogate a fundamental property right, such as the "right to exclude others," ${ }^{245}$ or the right to devise property to one's heirs, ${ }^{246}$ such an action is likely to weigh in favor of a taking. With respect to the latter, the Court in Hodel decided that the ability to control the disposition of property upon death through "complex inter vivos transactions such as revocable trusts" was not

\footnotetext{
240. Ruckelshaus, 467 U.S. at 1012.

241. Id. (quoting Webb's Fabulous Pharmacies, Inc. v. Beckwith, 449 U.S. 155, 164 (1980)) (other citations omitted). The Court refrained from definitively finding a takings problem at this stage, since it was possible that the negotiation and arbitration provisions of the statute might have resulted in "just compensation to Monsanto for the loss in the market value of its trade-secret data." Id. at 1013.

242. Connolly v. Pension Benefit Guar. Corp., 475 U.S. 211, 225 (1986).

243. Lingle v. Chevron U.S.A. Inc., 544 U.S. 528, 537 (2005) (quoting Armstrong v. United States, 364 U.S. 40, 49 (1960)).

244. See Cienega Gardens v. United States, 331 F.3d 1319, 1338-39 (Fed. Cir. 2003). But see Davidson, supra note 173 , at 4 (challenging the emerging equality dimension in regulatory takings analysis).

245. Kaiser Aetna v. United States, 444 U.S. 164, 176 (1979).

246. See, e.g., Hodel v. Irving, 481 U.S. 704, 716-717 (1987) (noting the extraordinary character of the action at issue: virtual abrogation of "the right to pass on a certain type of property - the small undivided interest - to one's heirs" in light of the fact that such a right "has been part of the AngloAmerican legal system since feudal times").
} 
an adequate substitute for the rights taken. ${ }^{247}$ Likewise, as mentioned above, the property interests at stake in Hodel were not de minimis. ${ }^{248}$ Both of these features further persuaded the Court that the character of the government action in abrogating an "essential" right was "extraordinary." 249

It is hard to know exactly how to apply these precedents to pre-1972 sound recordings. Together, they suggest that if the value of the pre-1972 sound recording copyrights were de minimis, the character of the government action might not weigh in favor of a taking. Since, however, it is unlikely that copyright with only de minimis value would be the subject of a constitutional challenge because it is doubtful that anyone would expend the funds to litigate, it is not clear that this tells us much. The other lesson appears to be that if roughly equivalent rights are substituted in place of the pre-1972 sound recording interests, that substitution might ameliorate the character of the government action. ${ }^{250}$ Certainly, if the earlier case Andrus v. Allard had continuing force, the "denial of one traditional property right does not always amount to a taking," $" 251$ and would not where "appellees retain the rights to possess and transport their property, and to donate or devise the protected birds."252

\section{Filing Obligations AND the Obligation to Make the Work REASONABLy AVAILABLE}

The proposed federalizing legislation requires that right holders of pre-1972 sound recordings take certain steps in order to preserve their rights to those recordings. Specifically, as mentioned, holders of published post-1923 recordings (and never-published recordings) would have to: (1) make, and continue to make, the recordings available to the public at a reasonable price and (2) file a notice with the Copyright Office confirming the availability of the recordings at a reasonable price, as well as that the owner intends to preserve his or her copyright protection until 2067..$^{253}$ For recordings published before 1923, similar steps are required, except that the protection may extend only as long as twenty-five years. ${ }^{254}$ Complying with these requirements may well entail some degree of financial hardship.

\footnotetext{
247. Id. at 716 .

248. Id. at 717 .

249. Id. at 716-17.

250. See Henry Lee Mann, As Our Heritage Crumbles into Dust: The Threat of State Law Protection for Pre-1972 Sound Recordings, 6 WAKE FoReST InTELL. PROP. L.J. 45, 52 (2006) (noting that "the drawback of the temporal limitation [on copyright holders] would be at least partially offset by the benefit of uniform and predictable protection, as is currently enjoyed by post-1972 sound recordings"); see also Erlinger, supra note 68, at 73-74 (grappling with trade-offs and stating that "[w] here the term of federal protection provided is significantly less than the term of state protection lost, the replacement begins to look more like a taking and less like an equitable tradeoff').

251. Andrus v. Allard, 444 U.S. 51, 65-66 (1979).

252. Id. at 66 .

253. See supra text accompanying notes $45-46$.

254. See supra text accompanying note 45 .
} 
The Supreme Court's decisions in Texaco, Inc. v. Short ${ }^{255}$ and United States $v$. Locke ${ }^{256}$ strongly indicate that these steps required to preserve ownership are constitutionally permissible. In Texaco, the Court considered an Indiana statute providing that segregated mineral interests not used for twenty years would automatically lapse and pass to the surface owner of the land, unless the mineral rights owner filed a statement with the county recording office within a two-year grace period. ${ }^{257}$ "Use" was defined to include mineral production, or the payment of rents, royalties or taxes. ${ }^{258}$ The purpose of this legislative provision was to extinguish "stale and abandoned" interests that impeded the public interest in the development of mineral and surface rights. ${ }^{259}$

In consolidated cases that arose over the ownership of certain mineral interests claimed to have lapsed, the Court held that the statute was constitutional. As an initial matter, the Court stated broadly that

[w] have no doubt that, just as a state may create a property interest that is entitled to constitutional protection, the State has the power to condition the permanent retention of that property right on the performance of reasonable conditions that indicate a present intention to retain the interest. ${ }^{260}$

The Court described the required filing of a statement of claim, in the absence of use, to be a "slight burden" on the mineral interest owners while providing "such clear benefits" to the public by identifying the owners of the interests from whom developers could acquire operating rights and the county could collect taxes. ${ }^{261}$ In Locke, the Court upheld an analogous federal scheme requiring holders of unpatented mining interests to make certain filings in order to preserve their interests. ${ }^{262}$ The purposes of the filings in that scheme were to eradicate stale mining claims and allow federal officials to make informed land management decisions. ${ }^{263}$ In both of these cases, the Court cited a long tradition of upholding legislation that required property owners to take affirmative steps in order to retain

\footnotetext{
255. Texaco, Inc. v. Short, 454 U.S. 516 (1982).

256. United States v. Locke, 471 U.S. 84 (1985).

257. Texaco, 454 U.S. at 518.

258. Id. at 519 .

259. Id. at 523 .

260. Id. at 526; accord Locke, 471 U.S. at 104 ("Even with respect to vested property rights, a legislature generally has the power to impose new regulatory constraints on the way in which those rights are used, or to condition their continued retention on performance of certain affirmative duties. As long as the constraint or duty imposed is a reasonable restriction designed to further legitimate legislative objectives, the legislature acts within its powers in imposing such new constraints or duties.").

261. Texaco, 454 U.S. at 529-30.

262. Locke, 471 U.S. at 109.

263. Id. at 87 . The Court did emphasize that unpatented mining claims are a "unique form of property" over which the government retains "substantial regulatory power." Id. at 104-05. However, its general statements about the right of government to condition the retention of property interests were just as broad as those in Texaco. And, in any event, given the history of reform of the copyright statute, one might say that copyright interests, too, remain subject to "substantial regulatory power."
} 
their rights. ${ }^{264}$

It is thus worth noting at the outset that such precedent also exists in the copyright context. The URAA's copyright restoration provisions, which have now been upheld by the Supreme Court, require right holders of "restored" copyrights in certain foreign works to file a notice of intent to enforce those rights against reliance parties - that is, against third parties who had been making use of the works. $^{265}$ The notices can be filed either with the Copyright Office or directly on the reliance parties. $^{266}$ While the Supreme Court did not directly pass on the takings or due process aspects of the requirement of filing these notices, their inclusion in the applicable statutory scheme reflects precedent for the sort of requirement being contemplated here.

Also permeating the Court's analyses in Texaco and Locke were undercurrents of the responsibilities of property ownership and the ability of government officials to identify those owners. In Texaco, there was demonstrated "neglect" - a failure of property owners to make productive "use" of the mineral rights, including the payment of taxes. $^{267}$ In Locke, more than six million unpatented mining claims existed on public lands, many of which were "dormant for decades" and impeded the government's ability to take any action regarding federal lands. ${ }^{268}$

In the case of pre-1972 sound recordings, the animating purposes of the federalizing legislation would reflect such a lack of stewardship. The legislation is aimed, in part, to ameliorate a widespread failure to preserve fragile, decaying sound recordings. ${ }^{269}$ Many copyright owners of older recordings simply are not in a position to preserve them and to make them available to the public. ${ }^{270}$ Simply put, the filing requirements would enable libraries and archives to preserve old recordings that have been abandoned. As in Texaco and Locke, the requirement of filing a notice to indicate an intention to retain the extended term of protection would be a strong indication that the interests have not been abandoned.

If the Public Meeting on Pre-1972 Sound Recordings was any indication, however, some opposition to the federalizing legislation may come from right holders of sound recordings that are in wide circulation and have been well preserved. ${ }^{271}$ Such parties might argue that any concerns about abandonment simply do not apply to their own well-known, economically valuable recordings. But the point of the filing requirements is precisely to address this problem by

264. Id. at 103-04; Texaco, 454 U.S. at 526-29.

265. 17 U.S.C. § 104A(c), (e) (2012); Golan v. Holder, 132 S. Ct. 873, 883 (2012).

266. 17 U.S.C. $\S 104 \mathrm{~A}(\mathrm{c}),(\mathrm{e})$.

267. Texaco, 454 U.S. at 529-30.

268. Locke, 471 U.S. at 86-87.

269. See COPYRIGHT OFFICE REPORT, supra note 5, at 90.

270. See id. at 60 .

271. See U.S. Copyright Office, Pre-1972 Sound Recordings Public Meeting (June 2, 2011), available at http://www.copyright.gov/docs/sound/meeting/transcript-06-02-2011.pdf; see also Comments of Recording Industry Ass'n of America (RIAA) and American Ass'n of Independent Music (A2IM) 7, 9-15 (Nov. 3, 2010), in U.S. Copyright OfFice, Comments REgarding Federal Copyright Protection of Sound ReCordings FiXed Before FeB. 15, 1972, available at http://www.copyright.gov/docs/sound/comments/initial. 
separating the wheat from the chaff-that is, separating the well-tended-to recordings from those that have been effectively abandoned. Many of the valuable rights are held by corporate entities which presumably have adequate records as to the recordings whose terms they would like to extend until 2067. They would thus be able to comply with the federalizing legislation.

Right holders with large catalogs may argue in response that the sheer number of filings they would have to make far surpasses what the Court characterized as a "slight burden" in Texaco. ${ }^{272}$ To address this problem, any statutory amendments and implementing regulations should streamline the filing process for right holders. In any event, the Court should give wide berth to the kinds of requirements that Congress imposes. In Locke, the imposition of both an initial and an annual filing requirement relating to already-existing property interests passed constitutional muster because the means were rational to support "clearly legitimate" legislative purposes. ${ }^{273}$ This was true even though, had every interest holder participated, the statute would potentially have required filings with respect to more than six million mining interests.

The Court's specific due process and takings pronouncements on these requirements will be briefly considered. With respect to generally applicable laws that alter substantive rights, constitutionally adequate process usually consists of "enacting the statute, publishing it, and, to the extent the statute regulates private conduct, affording those within the statute's reach a reasonable opportunity both to familiarize themselves with the general requirements imposed and to comply with those requirements." 274 The federalizing legislation would provide for a transition period in which a right holder would need to take certain steps to secure the maximum available extended term of protection. During that transition period, the right holder would need to make the work available to the public at a reasonable price and file a one-time notice verifying the work's availability and stating intent to achieve protection for the applicable extended term. ${ }^{275}$

This sort of transition period, in which property owners must take certain steps and file certain notices to preserve their interests, fits comfortably within the requirements of due process. In Texaco and Locke, for example, the Supreme Court approved both two- and three-year grace periods in which to make filings required to preclude deemed abandonment of the property interests at stake. ${ }^{276}$ Accordingly, as long as the federalizing legislation spells out the nature of the required notice and the definition of what it meant to make a work available at a

272. Texaco, 454 U.S. at 530.

273. Locke, 471 U.S. at 105-06. Holders of unpatented mining interests had to file both an initial claim with respect to the physical location of their interests and, annually thereafter, a notice of intention to hold the claim, an affidavit of assessment work performed on the claim or a detailed reporting form, or else they would face abandonment of the interest. Id. at 88-89. Technically, it was the annual filing requirement that gave rise to the dispute on appeal. $I d$.

274. Id. at 108 .

275. Under the federalizing legislation as currently formulated, the transition period is three years for sound recordings published before 1923, and six years for those published after 1923 or never published at all. See supra Part II.

276. Locke, 471 U.S. at 108; Texaco, 454 U.S. at 532-33. 
reasonable price, due process will be satisfied.

With respect to takings, the Court in Texaco held that the Takings Clause does not require compensation of an owner "for the consequences of his own neglect." 277 Under the applicable statute there, interests that were not used for twenty years and for which no claims were filed were deemed abandoned, and it was "the owner's failure to make any use of the property — and not the action of the State - that cause[d] the lapse of the property right." 278 Thus, the deprivation of these abandoned interests was not a taking. Nor was the requirement that a mineral interest holder come forward and file a claim, if he wanted to preserve the interest, itself a "taking." 279

In contrast to Texaco, the federalizing legislation would not preserve state law copyright interests based solely on the use of those recordings. So, for example, it would not be sufficient for a right holder to point to the wide circulation and sales of Elvis Presley and Ella Fitzgerald tracks to secure an extended federal term of protection until 2067. Rather, as stated, all right holders would have to make certain filings to secure the extended federal term, no matter how widely available their recordings. Nevertheless, this was exactly the set-up in Locke, which required filings - not just use - by all property owners who wished to retain their interests. ${ }^{280}$ The Court in Locke relied on Texaco to conclude that any property deprivation was based on the right holders' failure to comply with the "minimal burden" of annually filing the requisite documentation. ${ }^{281}$ Thus, the forfeiture of their rights was not a taking. ${ }^{282}$

\section{REgISTRATION}

Right holders of pre-1972 sound recordings would have to expend funds to register their recordings with the Copyright Office in order to qualify for statutory damages or to bring an action if the recording is a U.S. work. ${ }^{283}$ As of May 1, 2014 , registration fees are set at $\$ 55$ for an online registration and $\$ 85$ for a paper registration per work. ${ }^{284}$ These fees are required for all new works sought to be registered, and thus right holders of pre-1972 sound recordings would simply be placed in the same position as all other creators and owners. If followed, the Ninth

\footnotetext{
277. Texaco, 454 U.S. at 530.

278. Id.

279. Id.

280. See Locke, 471 U.S. at 106.

281. "Finally, the restriction attached to the continued retention of a mining claim imposes the most minimal of burdens on claimants; they must simply file a paper once a year indicating that the required assessment work has been performed or that they intend to hold the claim." Id.

282. See id. at 107 ("Regulation of property rights does not 'take' private property when an individual's reasonable, investment-backed expectations can continue to be realized as long as he complies with reasonable regulatory restrictions the legislature has imposed.").

283. See, e.g., 17 U.S.C. $\S \S 411,412$ (2012) (delineating registration as a prerequisite for these purposes in the case of works in other media).

284. See Copyright Office Fees, U.S. COPYRIGHT OFFICE, http://www.copyright.gov/fls/sl04_2014.
} pdf. 
Circuit's reasoning in Ladd v. Law \& Technology Press would seem to foreclose a takings claim on this ground. ${ }^{285}$ Citing Ruckelshaus v. Monsanto Co., the Ladd court said that "Congress indubitably can place conditions on the grant of a statutory benefit." 286 In deflecting challenges by the copyright holder that the deposit requirement is not a valid condition, the Ninth Circuit said that "[c]onditioning copyrights on a contribution to the Library of Congress furthers th[e] overall purpose" of the Copyright Clause. ${ }^{287}$ Even though deposit is not a precondition to copyright under the 1976 Act, it is still a requirement, and thus "precedent on statutory conditions," such as Ruckelshaus, is still applicable. ${ }^{288}$ Another option to consider, of course, is to modify the registration requirements for newly federalized pre-1972 sound recordings. ${ }^{289}$

\section{E. SUBSTITUTION OF FEDERAL RightS AND REMEDIES}

It is clear that the federalizing legislation contemplates not just a quantitative shift, but also a qualitative shift in the rights and remedies state copyright holders would enjoy and in users' defenses thereto. Federal rights and defenses would be put in place of state rights and defenses; federal remedies would replace state remedies. As discussed, with respect to rights, the federal regime generally offers right holders more-most prominently, an established derivative work right and public performance right (the latter with respect to digital audio transmissions). These rights, and others, would of course be subject to the same important exceptions and limitations that apply to uses of other works, such as fair use. With respect to remedies, although both systems allow for actual damages, the federal system would replace the possibility of punitive damages with the possibility of statutory damages beyond what is necessary to compensate the right holder. ${ }^{290}$

Therefore, the property right at stake in this context might be framed in a different way from those posited in the prior sections. Specifically, stakeholders might claim vested interests in a particular bundle of exclusive rights available under state law, or in a particular set of remedies. Accordingly, the Article next considers the due process and takings implications of claims framed in this way.

If, as hypothesized, the federalizing legislation were to become effective on January 1, 2015, many scenarios are imaginable; three will be addressed. First, parties might already be engaged in litigation on that date. For example, Party A might have sued Party B for making and distributing unauthorized copies of a

285. Ladd v. Law \& Tech. Press, 762 F.2d 809 (9th Cir. 1985).

286. Id. at 813 (citing Ruckelshaus v. Monsanto Co., 467 U.S. 986 (1984)).

287. Id. at 814; $c f$. Figueroa v. United States, 466 F.3d 1023, 1026 (Fed. Cir. 2006) (holding that Congress has wide constitutional latitude to impose patent application and issuance fees).

288. Ladd, 762 F.2d at 814 . Ladd also distinguished a line of cases limiting the federal government's ability, when acting in a proprietary rather than sovereign capacity, to appropriate patented devices. Id. at 814-15.

289. See, e.g., 17 U.S.C. § 411 (2012) (waiving registration requirement for copyright litigation involving non-U.S. works).

290. Federal copyright law also explicitly provides for non-monetary relief in the form of injunctions and impounding. 17 U.S.C. $\S \S 502,503$ (2012). 
sound recording fixed in 1965. The Supreme Court has held that a cause of action may be considered property protectable under the Due Process Clause. ${ }^{291}$ Where there is pending litigation, therefore, the case should be adjudicated under the preexisting state law. ${ }^{292}$ Such an application of state law would mean, for example, that punitive damages should remain available to Party A, but that Party A could not amend its complaint to claim a violation of a derivative work right (assuming such a right did not exist under state law). ${ }^{293}$ It would also mean that Party B could defend only on the basis of pre-existing state law defenses, which may or may not include fair use or other defenses.

A second scenario is that some time prior to January 1, 2015, Party C made unauthorized reproductions and distributions of sound recordings to which Party D holds rights. Let's assume that, also prior to January 1, 2015, Party D knew of Party C's activities and hired a lawyer to sue Party C, but that Party D did not actually file suit until January 1, 2016. In such a case, the cause of action has accrued before the effective date of legislation. Here, too, the best course of action to avoid due process problems is to adjudicate the case under state law, with the implications described above.

Both of these scenarios could be accomplished by modeling the federalizing legislation on the current $\S 301$ (b)(2) to remove from federal preemption the state law rights and remedies pertaining to "any cause of action arising from undertakings commenced before [its effective date]. ${ }^{294}$ In general, the reference to

291. See, e.g., Logan v. Zimmerman Brush Co., 455 U.S. 422, 428 (1982) (citing Mullane v. Cent. Hanover Bank \& Trust Co., 339 U.S. 306 (1950)) (noting that "a cause of action is a species of property protected by the Fourteenth Amendment's Due Process Clause").

292. As long as Congress was clear as to the temporal application of the federalizing legislation, see Landgraf v. USI Film Prods., 511 U.S. 244, 267-68 (1994), it is not entirely clear that application of the new (federal) law to such cases - even to the point of extinguishing pending state law claims in favor of federal claims - would necessarily pose a due process problem. See, e.g., Ileto v. Glock, Inc., 565 F.3d 1126, 1140-41 (9th Cir. 2009) (rejecting substantive due process challenge to federal legislation that preempted state tort law claims in pending cases); $c f$. Eddings v. Volkswagenwerk, A.G., 835 F.2d 1369, 1374 (11th Cir. 1988) (applying state supreme court decision to pending cases that had the effect of extinguishing plaintiffs' tort-based causes of action).

In Hammond v. United States, the plaintiff claimed that "the filing of a suit on an accrued common-law or state statutory cause of action gives her a vested property right in that action, and that Congress cannot retroactively abolish that cause of action and legislate the dismissal of plaintiff's suit without violating due process." 786 F.2d 8, 11 (1st Cir. 1986). The court rejected the due process challenge. $I d$. at $10-11$. First, it determined that "[b]ecause rights in tort do not vest until there is a final, unreviewable judgment, Congress abridged no vested rights of the plaintiff by enacting [the statutory provision] and retroactively abolishing her cause of action in tort." Id. at 12 . In any event, the statute passed rational basis scrutiny. Id. at 13-14; accord Ileto v. Glock, Inc., 565 F.3d 1126, 1140-41 (9th Cir. 2009). But see Ileto v. Glock, Inc., 565 F.3d 1126, 1148 (Berzon, J., concurring in part and dissenting in part) (citing Logan, 455 U.S. at 428, to conclude that a "pending cause of action, therefore, may be more or less valuable at various points during its pendency, but, even before it is reduced to a final dollar amount, it is a 'species of property protected by the ... Due Process Clause"').

293. Any prospective injunctive relief obtained under state law would need to expire at termination of new federal term.

294. 17 U.S.C. § 301(b)(2) (2012); see also § 301(c)(2) (“With respect to sound recordings fixed before [its effective date], any rights or remedies under the common law or statutes of any State shall not be annulled or limited by this title until February 15, 2067.”). 
"undertakings commenced" has been interpreted to mean "infringement[s] taking place." 295 Even clearer language, however, could be chosen to solidify the point.

A third scenario is as follows: After January 1, 2015, Party E makes unauthorized reproductions and distributions of Party F's recordings. At this point, federal law would apply to the case of Party $F v$. Party $E$, and it seems clear that the application of federal law would comport with due process. ${ }^{296}$ Conceivably, however, a disaffected right holder might object that the mere displacement by federal law of the state law regime governing pre-1972 sound recordings violates due process.

In Duke Power Co. v. Carolina Environmental Study Group, Inc., however, the Court rejected a similar due process challenge to the federal Price-Anderson Act, which capped private and government liability in the event of a nuclear incident. ${ }^{297}$ Without any nuclear incident having occurred, objectors claimed that the "liabilitylimitation provision . . . fails to provide those injured by a nuclear accident with a satisfactory quid pro quo for the common-law rights of recovery" that the federal law abrogates. ${ }^{298}$ Noting, as an initial matter, that it is not even clear that due process requires that a "legislatively enacted compensation scheme either duplicate the recovery at common law or provide a reasonable substitute remedy," the Court determined that, in any event, the federal act does "provide a reasonably just substitute for the common-law or state tort law remedies it replaces" and satisfies due process requirements. ${ }^{299}$ The legislative history reflected "Congress' determination that reliance on state tort law remedies and state-court procedures was an unsatisfactory approach to assuring public compensation for nuclear accidents, while at the same time providing the necessary incentives for private development of nuclear-produced energy." 300 Thus, the statutory limitations on liability bore a "rational relationship" to Congress's goal of increasing private production of such energy sources. ${ }^{301}$

Applying this reasoning to the pre-1972 sound recordings context, it seems

295. 1 NIMMER ON COPYRIGHT, supra note 10, § 1.01[C] (collecting cases).

296. See e.g., Ducharme v. Merrill-Nat'l Labs., 574 F.2d 1307, 1310 (5th Cir. 1978) (concluding that because plaintiffs' cause of action did not arise until after passage of the federal act, they had "no prior vested right in a cause of action under" state law and rejecting due process claim); Carr v. United States, 422 F.2d 1007, 1010-11 (4th Cir. 1970) (same); accord Jeremy A. Blumenthal, Legal Claims as Private Property: Implications for Eminent Domain, 36 Hastings Const. L.Q. 373, 398 (2009) ("Prospective regulations that diminish or eliminate unaccrued causes of action (or defenses) do not implicate property rights."); Radin, supra note 115, at 1328 (arguing that "[c]hanges to accrued rights (retroactive change) can implicate a property interest, while changes to nonaccured rights (prospective change) should not" and that accrual occurs "once a party can determine the legal consequences of an action because the injury has happened and the law at the time of injury is known").

297. See Duke Power Co. v. Carolina Envtl. Study Grp., Inc., 438 U.S. 59, 64-67 (1978); see also Silver v. Silver, 280 U.S. 117, 122 (1929) ("[T]he Constitution does not forbid the creation of new rights, or the abolition of old ones recognized by the common law, to attain a permissible legislative object.").

298. See Duke Power, 438 U.S. at $87-88$.

299. See id. at 88 .

300. See id. at 89.

301. See id. at 84 . 
readily apparent that as long as the federalizing legislation bears a rational relationship to a legitimate legislative goal, which this Article argues it does, then the mere substitution of federal rights and remedies will not trigger a due process violation. The Court has approved these sorts of legislative substitutions in the past. ${ }^{302}$ And, as in Duke Power, the federal rights and remedies - while not exactly co-extensive-are "reasonably just substitute[s]" for the state law rights and remedies they replace. ${ }^{303}$ Moreover, the revocation of punitive damages in favor of a statutory damages scheme should not be deemed to violate due process even if it can be demonstrated that statutory damages generally yield a smaller monetary award for right holders successful in litigation. In approving the substitution of workers' compensation regimes in place of common law standards (and as reaffirmed in Duke Power) due process is not violated "simply because an injured party would not be able to recover as much under the Act as before its enactment." 304

Courts should be reluctant to find a cognizable takings claim based solely on an objection to the substitution of governing regimes. ${ }^{305}$ While there is limited Supreme Court precedent directly on point, considerable precedent from the Ninth Circuit strongly suggests that this line of argument would not be fruitful for stakeholders. ${ }^{306}$ For example, that court recently rejected a takings claim raised by plaintiffs challenging the legislative revision of a state program whereby property owners could seek either just compensation or exemptions from land use regulations. ${ }^{307}$ The new law curtailed the remedies and processes available to property owners who had already begun seeking relief under the old program. ${ }^{308}$ Indeed, the plaintiffs had all been granted exemptions prior to the revision but, following the legislative overhaul, were unable to develop their land pursuant to the

302. We have not here distinguished at a more granular level among causes of action that are based on tort, contract or property. There is some support for the notion that the abridgment of accrued causes of action to enforce vested intellectual property rights created by statute is more suspect than the abridgement of the typical tort cause of action. See Hammond v. United States, 786 F.2d 8, 11 (1st Cir. 1986) (citing Richmond Screw Anchor Co. v. United States, 275 U.S. 331 (1928), which dealt with patent rights). But, as the Hammond court noted, the "vitality [of such older cases] may now be in doubt because more recent cases have upheld retroactive application of statutes that abridge economic and real property rights created under a prior statute without always carefully distinguishing the older cases." Id. at 11 .

303. Accord Bowers v. Whitman, 671 F.3d 905, 917 (9th Cir. 2012) (rejecting substantive due process challenge where state replaced one set of remedies with another set of remedies).

304. Duke Power, 438 U.S. at 93 (citing N.Y. Cent. R.R. Co. v. White, 243 U.S. 188, 201 (1917)).

305. One commentator, surveying the case law, suggests that "courts rarely treat legal rights as private property for purposes of the Takings Clause.” Radin, supra note 115, at 1319.

306. In Duke Power, for example, the Court essentially found such a claim too speculative because it assumed that compensation for physical property damage would still be available under the Tucker Act. See Duke Power, 438 U.S. at 94 n.39; see also In re Consol. U.S. Atmospheric Testing Litig., 820 F.2d 982 (9th Cir. 1987) (concluding that federal statute, which substituted a remedy against the government under the Federal Tort Claims Act for causes of action against contractors arising under state law, did not effect a taking).

307. See Bowers, 671 F.3d at 909-910.

308. See id. at 910. 
exemptions; nor had they received any monetary compensation. ${ }^{309}$

The court rejected the plaintiffs' claim to property in the form of an accrued cause of action under the prior law. ${ }^{310}$ The court underscored that "although a cause of action is a species of property, a party's property right in any cause of action does not vest until a final unreviewable judgment is obtained," because the interest is still inchoate and does not afford certainty of expectation. ${ }^{311}$ The exemptions previously granted failed in and of themselves to convey vested interests because they did not entitle the property owners to any particular compensation or use of their property. Because the plaintiffs had at most only a cause of action and not a final judgment under the prior law, they possessed an insufficient property interest. "Their right to sue," said the court, "was therefore not a property interest protected by the Takings Clause." $" 312$ In another case, the same court put the point more bluntly: "a plaintiff's interest in a prospective punitive damages award does not qualify as 'property' under the Takings Clause." 313

Such precedent suggests that courts should reject a takings claim based on the mere displacement of state rights and remedies by federal rights and remedies.

\section{F. RESTRICTIONS ON USERS}

The federalizing legislation could effectively restrict the activities of users who engaged in activities that were permitted (or at least tolerated) under state law-for example, certain noncommercial uses. This Article next examines the likelihood that such users might successfully raise a due process or takings claim. ${ }^{314}$

The Golan v. Gonzales case addressed a due process claim in somewhat analogous circumstances. ${ }^{315}$ The subject of the Golan case was the Uruguay Round Agreements Act (URAA), which restored the copyrights in certain works of foreign origin that had been in the public domain in the United States. ${ }^{316}$ The Golan plaintiffs claimed that the law impermissibly curtailed their use of those works, which they had exploited in reliance on those works being (and remaining) in the public domain. They argued, inter alia, that the URAA imposed retroactive burdens on them and that the provisions in the law designed to protect them as

309. See id. at 911.

310. See id. at 913.

311. Id. at 914 (citations and internal quotation marks omitted).

312. Id. The court also rejected a takings argument on the ground of a statutory entitlement to compensation because, among other things, "no monetary commitment was unequivocally made." Id. at 915. Nor had plaintiffs exhausted the remedies that were available to them. See id. at 916.

313. Engquist v. Or. Dept. of Agric., 478 F.3d 985, 1004 (9th Cir. 2007).

314. As one commentator has pointed out, often it can be more difficult for defendants than plaintiffs to persuade courts as to retroactivity problems. See Radin, supra note 115, at 1344 (noting that "defendants find it difficult to successfully challenge statutes that retroactively create new rights of action because they cannot point to an explicit legal right that the legislation impaired").

315. See Golan v. Gonzales, No. Civ.01-B-1854(BNB), 2005 WL 914754 (D. Colo. Apr. 20, 2005), aff'd, 501 F.3d 1179 (10th Cir. 2007), remanded to Golan v. Holder, 611 F. Supp. 2d 1165 (D. Colo. 2009), rev'd, remanded to 609 F.3d 1076, (10th Cir. 2010), aff'd, 132 S. Ct. 873 (2012).

316. See supra notes $32-37$ and accompanying text. 
reliance parties were insufficient. ${ }^{317}$ According to plaintiffs, the law effectively denied them their Fifth Amendment right to due process.

The district court acknowledged that plaintiffs had invested in uses of the works, but rejected their contention that the URAA imposed retroactive burdens on them. The court explained that "[a] statute does not operate retrospectively merely because it is applied in a case arising from conduct antedating the statute's enactment, or upsets expectations based in prior law." 318 The court went on to observe that whether a change to the law operates retroactively depends on the "nature and extent" of the change and "the degree of connection between the operation of the new rule and the relevant past event." 319 It held that "[t]hough the plaintiffs reasonably relied upon the entry of the works at issue into the public domain, any expectations they had of perpetual rights of exploitation could not reasonably have been settled." ${ }^{\prime 20}$ The court explained that because Congress had on several occasions removed works from the public domain, plaintiffs' rights were "anything but inviolate." 321

Even if copyright restoration were considered retroactive in effect, according to the court, it would not violate the Fifth Amendment since it is rationally related to a legitimate government objective-extending protection to foreign authors to achieve similar protection for U.S. authors abroad - and it contains provisions to ameliorate its effect on reliance parties. ${ }^{322}$ The plaintiffs apparently did not pursue the due process claim on appeal, ${ }^{323}$ so neither the Tenth Circuit Court of Appeals nor the Supreme Court had an opportunity to rule on it.

Any claim that the federalizing legislation under discussion would defeat users' expectations of perpetual rights of exploitation in pre-1972 sound recordings appears to be weaker than that mounted in Golan, where most of the restored works were in the public domain throughout the United States. The uncertainty of the law, the evolving nature of common law and the existence of strong protection in some states would make it difficult for a challenger to claim its expectations were reasonable. Moreover, there is little doubt that Congress, in enacting the federalizing legislation, would be pursuing legitimate government objectivescreating a single regime of protection for sound recordings, and enhancing the ability to preserve and use pre-1972 recordings - in a rational manner.

One commentator has suggested that the federalizing legislation should contain a graduated phase-in aspect, modeled after the URAA, by which users who were

317. For example, the law provides that a reliance party who was using a restored work prior to restoration may continue to exploit existing copies for one year after that party receives actual or constructive notice of the right holder's intent to enforce the copyright. See 17 U.S.C. § 104A(d)(2), (e) (2012). If the reliance party had created a derivative work prior to restoration, the reliance party could continue to use the work if it compensated the right holder. See id. $\$ 104 \mathrm{~A}(\mathrm{~d})(2)$.

318. Golan, 2005 WL 914754, at *17 (quoting Landgraf v. USI Film Prods., 511 U.S. 244, 269 (1994) (citations omitted))

319. Id. at $* 18$.

320. Id.

321. Id.

322. See id.

323. See Golan v. Gonzales, 501 F.3d 1179, 1181-82 (10th Cir. 2007). 
"reliance parties" - that is, who "made investments and agreements for the use of a sound recording in a context that is permissible under state law but improper under federal law"- - would have a chance to adjust their behavior before being deemed copyright infringers. ${ }^{324}$

It also seems unlikely that a court would recognize a takings claim asserted on behalf of users who would argue that their use of pre-1972 sound recordings prior to federalization established a cognizable property interest. As discussed above in Part V.E., this appears to be a mere substitution of regimes, which would result in more clearly defined and consistently available exceptions and limitations. Indeed, it is telling that users (including libraries), rather than right holders, have been the primary motivating force behind the initiative to federalize pre-1972 sound recordings, with many claiming that federal exceptions are more certain and predictable than what state law provides. ${ }^{325}$

There is no Supreme Court precedent directly on point. In Golan v. Holder, however, the Court rejected the claim that pre-restoration users of foreign works whose U.S. copyrights were restored by the URAA established a vested First Amendment interest that entitled them to continue to use the restored works without obligation to the right holders. ${ }^{326}$ In fact, a claim that use of pre-1972 sound recordings prior to their federalization established an ownership interest in those recordings appears weaker than the claim made in Golan. Arguably some of pre-1972 recordings were effectively in the public domain in some states. But in other states, those recordings could not be considered to be in the public domain, and any property rights therefore belong to the initial right holders and their transferees, rather than to users.

\section{CONCLUSION}

To conclude, if Congress were to adopt the type of proposal offered by the Copyright Office, cognizant of the modifications suggested herein, it should significantly alleviate the principal takings and due process concerns that have been discussed. Such legislation could serve as a helpful framework for future legislative amendments to the intellectual property laws.

324. Erlinger, supra note 68, at 76-77.

325. E.g., Loughney, Comments of Library of Congress in Response to Notice of Inquiry, supra note 28, at 1, 3-5; Brooks, Comments at Pre-1972 Sound Recordings Public Meeting, supra note 28, at 18-19. But see Brandon Butler, Ass'n of Research Libraries, Comments at Pre-1972 Sound Recordings Public Meeting 155-60 (June 2, 2011), available at http://www.copyright.gov/docs/sound/meeting/ transcript-06-02-2011.pdf.

326. See Golan v. Holder, 132 S. Ct. 873 (2012). 